\title{
SELECTIVE CIVILIAN TARGETING: THE UNINTENDED CONSEQUENCES OF PARTIAL PEACE
}

\author{
MOUNU PREM ${ }^{\ddagger}$, ANDRÉS F. RIVERA ${ }^{\star}$, DARIO A. ROMERO ${ }^{\dagger}$, AND JUAN F. VARGAS $^{\Uparrow}$
}

This version: June 2020

\begin{abstract}
Peace agreements may inadvertently increase selective violence against civilians when they are incomplete in two key dimensions. First, only a fraction of the existing armed groups participates of the agreement. Second, the legitimate government fails to establish institutional presence in the areas previously controlled by those who do participate. Under these two conditions, the resulting vacuum of power may attract active armed groups who engage in selective civilian victimization to obtain control. Studying the recent Colombian experience, we find that the permanent ceasefire declared by the FARC insurgency in 2014 led to a surge in the targeting of community leaders in former FARC strongholds, perpetrated by armed groups excluded from the peace process, with the goal of consolidating their dominance in those areas. Critically, selective victimization is attenuated by some dimensions of state capacity and exacerbated in places which are more valuable as proxied by the existence of recent land conflicts.
\end{abstract}

JEL CODES: D72, D74

KEYwords: Selective civilian targeting, Peace process, Armed conflict, Territorial control

This paper circulated previously under the name "Killing Social Leaders for Territorial Control: The Unintended Consequences of Peace". We thank Adriana Camacho, Giacomo De Luca, Héctor Galindo, Jorge Gallego, Felipe González, Dorothy Kronick, Luis Martinez, Nicola Mastrocco, Pablo Querubín, Andrés Rosas, Martin Rossi, Fabio Sánchez, Santiago Saavedra, Jacob Shapiro, Abbey Steele, Mateo Uribe, Austin Wright and seminar participants at the Columbia University Development Colloquium, the 2018 Annual Workshop of the Households in Conflict Network, the 2018 LACEA-LAMES Annual Conference, Rosario-Andes Taller Applied (RATA), Universidad Javeriana, the 1st Colombian Economic Conference and the $5^{t h}$ Workshop on the Economics of Organized Crime for helpful comments and suggestions. We are especially grateful to Charu Prem for in depth comments at various stages of the project.

${ }^{\ddagger}$ School of Economics, Universidad del Rosario. Calle $12 \mathrm{C}$ No. 4-69, Bogotá. E-mail: francisco.munoz@urosario.edu.co.

${ }^{\star}$ School of Economics, Universidad del Rosario. Calle 12C No. 4-69, Bogotá.E-mail: andresfel.rivera@urosario.edu.co.

${ }^{\dagger}$ Department of Economics, Columbia University. 1022 International Affairs Building, 420 West 118th Street, New York, NY 10027. E-mail: dr2879@columbia.edu.

ฯ Corresponding author. School of Economics, Universidad del Rosario. Calle 12C No. 4-69, Bogotá. E-mail juan.vargas@urosario.edu.co. 


\section{InTRODUCTION}

Peace agreements are usually imperfect and far from comprehensive. They need to address the specificities of particular conflicts, and are shaped by both internal and external political constraints (Doyle and Sambanis, 2000). Indeed, the concept of 'peace' goes well beyond the absence of war and should "incorporate the conditions under which states have little need or incentive to use violence against their citizens, and conversely citizens have little motivation or incentive to challenge the state by force of arms" (Regan, 2014). This constitutes a magnificent challenge. For instance, a large body of literature has studied how peace "spoilers" - organized (armed or unarmed, local or international) groups or leaders-attempt to undermine peace agreements with violent, economic or political pressure in a variety of contexts (See for example Stedman, 1997; Newman et al., 2006; Hoddie and Hartzell, 2010; Le Billon, 2012).

The limitations of peacemaking are exacerbated in internal conflicts with multiple actors if a peace deal is made with only a fraction of the active armed groups. The probability that in multi-party conflicts all stakeholders simultaneously favor peace over fighting is very low (Stedman, 2003). Moreover, in such circumstances, there is no guarantee that violence will end, and in fact conflict levels may even increase. ${ }^{1}$

An additional factor that can aggravate the unintended security deterioration following peace agreements is the government's failure to establish institutional presence in areas formerly controlled by the groups with whom a peace agreement is made. Lack of state capacity in the territory has been shown to favor the incidence of violence (e.g. Fearon and Laitin, 2003; Ch et al., 2018), especially in settings of rugged terrain such as Colombia, Afghanistan, Peru and many others (Carter et al., 2019). Because non-state actors often establish state-like social order within the specific strategic territories that they control (Arjona, 2016), their withdrawal following the peace agreement may result in violent territorial contestation by other (non-state) organizations if the government does not protect and institutionalize these

${ }^{1}$ Franke and Öztürk (2015) and König et al. (2017) show that, when there are more than two parties involved in conflicts with complex network structures, partial peace deals may backfire. 
territories first.

Based on these two observations, we posit that partial peace agreements, that fail both to incorporate all the existing armed groups and to establish institutional presence in areas previously controlled by the groups who do participate of the agreement, generate a vacuum of power in some territories that may attract active armed groups. In turn, such armed groups are likely to engage in selective civilian victimization disproportionally targeted against local leaders. This is because local leaders help mobilize communities to demand redistributive policies, implement local development projects, and denounce malfeasance of local politicians as well as human rights abuses (CINEP, 2020; Lobo et al., 2016). This makes some types of leaders an obstacle to many economic and political interests, and thus at risk of being targeted by armed groups who seek territorial dominance and oppose land restitution, environmental protection, or the voluntary substitution of illegal crops among other local development initiatives.

In order to provide formal empirical support to our conjecture using fine-grained subnational longitudinal variation, we study the recent experience of Colombia. After over five decades of civil war, at the end of 2016 the government signed a peace agreement with the country's largest and oldest guerrilla, the Revolutionary Armed Forces of Colombia (FARC from the Spanish acronym). While the conflict with FARC ended as a result of the agreement, other groups such as the National Liberation Army (ELN from the Spanish acronym), criminal bands of former paramilitary groups, and FARC dissidents that opposed an agreement with the government, were excluded from the negotiations.

At the end of 2014 the final stage of the peace negotiations began. As a way to signal both commitment toward ending the war and internal cohesiveness, FARC declared a permanent ceasefire that precluded both any armed confrontation with government as well as any dispute against other illegal armed groups. The ceasefire was largely met until replaced in August 2016 by the definitive ceasefire and the subsequent disarmament of FARC. In this respect, the ceasefire is the de facto end of FARC as an insurgent group, and it provides a 
cleaner temporal variation than the actual signature of the peace agreement.

Most importantly, the ceasefire constituted a clear incentive for other armed groups to attempt achieving the control of FARC strongholds, especially since the government forces failed to occupy and build institutional capacity in such areas (see section 2.2 for a discussion of the available qualitative evidence). This resulted in the systematic assassination of local community leaders. The final peace agreement, signed at the end of 2016, is probably the most important political achievement for a country that faced over five decades of internal armed conflict. However, the simultaneous unprecedented surge in the assassination of social leaders, which we study in this paper, casted a shadow over the euphoria generated by the end of the conflict with FARC.

Our estimation strategy exploits the temporal variation provided by the permanent ceasefire and the spatial variation given by pre-ceasefire FARC territorial dominance as well as the proximity of areas with presence of other armed groups which were excluded from the peace agreement. Since closer targets are easier to be attacked in irregular wars (Mueller et al., 2019), this proximity determines the cost advantage of other armed groups in disputing former FARC strongholds given the vacuum of power created by the ceasefire and the subsequent FARC withdrawal to a handful of territories.

We find that the killing of social leaders increased disproportionally after the start of FARC's permanent ceasefire in places previously dominated by this insurgency and located in the proximity of areas with presence of other armed groups. Consistent with our theoretical argument, we find no disproportionate surge of selective civilian victimization after the ceasefire neither in former FARC strongholds that are not disputed by other armed groups nor in places that are close to other armed groups but did not use to be controlled by FARC. Moreover, our results suggest that killing of social leaders is not driven by a differential trend of the overall homicide rate, and thus it is not explained by either a strategy of indiscriminate killings of civilians (or a differential change of reporting rates in previously FARC-controlled areas after the ceasefire). 
This paper contributes to the existing literature in several ways. First, we emphasize how peace agreements may backfire if they generate territorial vacuums of power that are not quickly filled by the legitimate state. In particular, our results suggest that partial pacification processes can exacerbate violence by other existing armed groups, aimed at controlling pacified territories. Indeed, the killing of social leaders in Colombia has largely undermined the legitimacy of the peace agreement. Second, we contribute to the recent literature about the factors that help the success of violence reduction security programs (see for instance Fearon et al., 2009; Berman et al., 2013; Hartman et al., 2021), by exploring what mechanisms exacerbate or attenuate the killing of social leaders following the ceasefire. Specifically, we emphasize the importance of state capacity, judicial effectiveness, and well-specified land property rights in reducing the incentives of other armed groups to target social leaders for territorial domination. Third, our paper also relates to the literature studying how policies aimed at reducing illegal activities can increase violence in the form of armed territorial disputes (see for example Werb et al., 2011 and Dell, 2015). Finally, this paper contributes to a growing literature regarding the consequences of Colombia's peace agreement with FARC (see, e.g., Prem et al., 2020, 2021b; Guerra-Cújar et al., 2020).

\section{Partial peace and selective Civilian targeting in multi-Party Conflicts}

In this section we highlight our contribution considering the existing literature. This paper does not propose a novel theory of selective civilian targeting. Rather, our argument emphasizes how the territorial contestation, a key element of most theories, interacts in multi-party conflicts with weak state capacity so that selective civilian targeting can become systematic, widespread, and persistent to an extent of threatening the stability of a peace agreement. The second contribution of our paper is empirical. While we provide rigorous and robust evidence for Colombia, we believe that our findings extend to most multi-party conflicts for which peace agreements are partial and state capacity lacking.

2.1. Civilian victimization. Civilian targeting has been considered a central driver of civil war violence at least since the work of Galula (1964), Clutterbuck (1966), and Thompson 
(1966). An extensive literature has argued that violence against civilians in civil war is neither the result of irrational factors such as emotions nor driven by pre-existing ideological disputes, but rather responds to strategies, incentives, and constraints. This literature is vast, and a far from comprehensive list includes Mason and Krane (1989); Goodwin (2001); Kalyvas (2006); Humpreys and Weinstein (2006); Eck and Hultman (2007); Downes (2007); Kalyvas and Kocher (2007); Lyall (2009); Kocher et al. (2011); Condra and Shapiro (2012); Lyall et al. (2013); Toft and Zhukov (2015); Schwartz and Straus (2018); and Huber (2019). ${ }^{2}$ Several accounts of civilian targeting in civil war distinguish between indiscriminate and selective violence. ${ }^{3}$

The former does not take into account the identity and behavior of victims, and often backfires (Kalyvas, 2006; Lyall, 2019). This occurs because, when civilian violence is executed en masse, it exacerbates existing grievances and creates new discontent among civilians, who seek revenge against the perpetrators of violence and may thus share information with or even join rival armed groups. ${ }^{4}$ This can be exacerbated if, as a result of the indiscriminate violence, assets and other sources of income get destroyed thus lowering the opportunity cost for civilians of joining an armed group (Dube and Vargas, 2013; Blattman and Annan, 2016).

In turn, selective violence occurs when targets are chosen on the basis of their identity and actions. It is perpetrated to create fear among civilians in order to encourage support allegiance in contexts of territorial contestation such as the setting studied in this paper (Kalyvas, 2006; Wood, 2010; Vargas, 2016; De la Calle, 2017). Indeed, our argument that FARC's de facto withdrawal from its strongholds following its declared permanent ceasefire attracted other armed groups that sought to control these territories and, to that end, engaged in the killing of key local community leaders, is consistent with several theories of

${ }^{2}$ See Lyall (2019) and Berman and Matanoc (2015) for recent reviews.

${ }^{3}$ Steele (2017) discusses yet another category: 'collective' targeting occurs when entire communities are targeted based on a shared non-ethnic characteristic, such as their political alignment.

${ }^{4}$ On the provision of information to rivals, see Berman et al. (2011) and Shaver et al. (2016). Balcells (2017) and Petersen (2001) provide examples of revenge-seeking civilian mobilization for the cases of the Spanish Civil War and the anti-Soviet resistance in Lithuania, respectively. 
selective civilian targeting.

For instance, Kalyvas (2006) argues that the amount of selective violence perpetrated by an armed group is inversely related to their level of territorial control: the higher the control, the less necessary it is that the armed group engages in violence. Further, to Wood (2010), the engagement in violence against civilians is related to insurgent capacity: weak groups cannot obtain civilian loyalty by providing selective benefits (such as security provision) and thus have an incentive to (temporarily) target civilians to expand the support infrastructure. In contrast, more capable and stronger rebels can rely more on benefits to sustain allegiance. Finally, De la Calle (2017) discusses how in already consolidated areas rebels seek to remain clandestine and civilian targeting is avoided because, otherwise, communities could turn against armed groups and bring down the clandestine structures.

While there are other theories that deal with civilian victimization in contexts other than territorial contestation (e.g. Alesina et al. (2019) and Robinson and Torvik (2009) emphasize the electoral incentives that motivate the use of violence against civilians), all these accounts are observationally consistent with our argument that the start of the permanent ceasefire and the subsequent territorial dispute that other armed groups engaged in former FARC strongholds triggered a cycle of selective targeting of civilians. But in our context there are other key ingredients that make the recent Colombia experience salient because of the large, widespread, systematic, and persistent trend in the assassination of local community leaders.

2.2. Lack of state capacity and the power vacuum. First, with the exception of Wood (2010), the theories of civilian targeting in civil war do not directly discuss how varying levels of state capacity at the local level can either exacerbate or attenuate violence. Even Wood (2010) limits his analysis to state-inflicted violence (which interacts with the rebels' own strength to determine the intensity of civilian targeting). But the state's institutional presence (both military and otherwise) is rarely accounted for in the study of violence against civilians. This contrasts with the strand of the literature that has studied the relationship between state capacity and the success of peace building efforts in post-conflict settings (see 
for example DeRouen Jr et al., 2010). Post-conflict reconstruction hinges not only upon governments' ability to consolidate the monopoly of violence in the territory, but also upon its institutional presence to support legal economic activities, the consolidation of an active civic society, and the sound implementation of the peace agreement. Examples of how peace agreements have failed because of state weakness include Somalia and Burundi. ${ }^{5}$

We join these two literatures (the study of selective civilian targeting and the role of state capacity in promoting resilient peace agreements) and argue that the lack of state presence at the local level exacerbates the vacuum of power generated by the de facto demobilization of an armed group and thus increases the incentive for other armed groups to seek control of these strategic territories. As argued above, the need to consolidate an initial critical mass of supporters, informants, and providers of supplies and shelter pushes these groups to selectively target community leaders. In turn, a weak an absent state that is unable to provide security and fails to implement the provisions of the peace agreement at the local level will exacerbate these incentives.

In the case of Colombia, anecdotal evidence largely suggests that, neither during the peace negotiations (amidst which the ceasefire was declared) nor after the peace agreement was signed, the government was able to occupy FARC strongholds. For instance, in 2015 President Juan Manuel Santos dismantled the Unidad Administrativa Especial para la Consolidación Territorial, a government's bureau that was created in 2011 and was tasked with the goal of establishing institutional presence in the territories formerly controlled by armed groups. Moreover, while the implementation of the peace agreement was supposed to focus on 170 municipalities that had been traditionally vulnerable to conflict activity (the so called Development Programs with Territorial Focus, PDET from the Spanish acronym), this initiative did not take off before the end of our sample period.

By and large, the weakness of the Colombian state in some parts of the territory is responsible for the failure of the government's recent attempts to protect local social leaders. In

\footnotetext{
${ }^{5} \mathrm{~A}$ related but different branch of the literature focuses on the relationship between state capacity and civil war onset (Fearon and Laitin, 2003; Taydas and Peksen, 2012).
} 
2016, the National Protection Unit (UNP from its Spanish acronym) increased the protection schemes available to human rights defenders and other civilians whose life had been threatened. However, the budget of the UNP is too low relative to the number of people who request protection. According to Human Rights Watch (2021), out of 13,000 protection requests received in 2019, the UNP only afforded to protect 1,900 people. In addition to the lack of budget, there have been complaints about the cumbersome requirements imposed by the UNP to provide protection, as well as about the UNP's understaffing and delays to granting protection schemes (Human Rights Watch, 2021). Moreover, protection schemes may backfire as they draw attention. The government also implemented an early warning system based on threat reports. However, while $90 \%$ of the alerts corresponded to threats against social leaders, at least a third of them eventually ended up being killed (Human Rights Watch, 2021).

2.3. Multy-party conflict. A third ingredient for our observed empirical patterns (a widespread, large, and persistent victimization of local community leaders) is that the resulting power vacuum is binding. This means that there must be other illegal actors that are attracted by the window of opportunity of ruling new strategic territories. This is the case on conflicts that feature multiple armed groups. We posit that the type of territorial disputes that are more likely to be conducive to selective civilian killing are precisely those that result from partial peace agreements featuring civil wars with a multiplicity of actors. This is not exceptional, Christia (2012) studies 'multiparty' civil wars (civil wars in which there are three or more major domestic combatant groups) and finds that these constitute a sizable subsample (about half of all the conflict years) of all civil wars defined by Fearon and Laitin (2003). In addition to Colombia, salient examples include Afghanistan, Bosnia, Lebanon, and Iraq.

2.4. Our argument. Each one of these phenomena (civilian targeting in the context of territorial contestation, multi-party conflicts, partial peace agreements, and power vacuums due to state weakness) have been studied in the literature, albeit mostly independently from one another. 
Our main focus is on the first factor and document that, instead of being a localized and short-lasting episode of civilian victimization, the recent extraordinary surge in the killing of local community leaders in Colombia is both widespread and persistent. We argue that this is likely explained by the fact that the territorial contestation that resulted from FARC's de facto withdrawal from its strongholds following the permanent ceasefire declared in late 2014, coexisted with other key factors, such as the existence of multiple illegal armed groups and the lack of state capacity (after a long history of armed conflict in a highly fragmented territory).

In this sense, Colombia is not exceptional. Our argument is consistent with several historical and contemporaneous case studies, in which incomplete peace agreements paired with territorial disputes have resulted in the escalation of selective targeting of civilians. Examples include the Indo-Sri Lanka Peace Accord in 1987 (which excluded the Tamil Tigers), the Arusha Accords in 2000 (which excluded the CNDD-FDD), and most of Myanmar's bilateral ceasefires that preceded the Nationwide Ceasefire Agreement in 2015. In addition, the cases of Guatemala, Sierra Leone, and Nepal stand out to illustrate how partial peace agreements and territorial power vacuums result in selective civilian victimization.

\section{BACKGROUND}

3.1. The Colombian conflict and the recent peace process. The Colombian civil war started with the foundation of left-wing guerrillas FARC and ELN in the mid 1960s. Both groups claim to represent the rural poor and have fought for over 50 years with the stated aim of overthrowing the government. In order to finance the protracted war, both groups have been profiting from several forms of illegal activities localized within the Colombian territory (Richani, 1997). This implies that sub-national territorial dominance is an important intermediate objective of the armed groups.

The conflict was a Cold War proxy until the end of the 1980s, but escalated during the 1990s fueled by the involvement of the guerrillas in illegal drug trafficking and the consolidation of right wing paramilitary groups. The formation of paramilitary groups dates back to the 
late 1960s. As part of the war against "internal enemies," the US National Security Doctrine legitimized the military as the force ultimately responsible for security and development in Latin America. In Colombia, this encouraged the enactment of Decree 3398 of 1965 and Law 48 of 1968, which allowed civilians to be trained and armed by the military to fight the newly created communist insurgencies. ${ }^{6}$

In the mid 1990s, the paramilitaries effectively became a third force in the conflict, when splintered paramilitary armies colluded under the umbrella organization of the United SelfDefense Groups of Colombia (AUC by its Spanish acronym). Through the end of the 1990s and the first half of the 2000s, the counterinsurgency strategy of paramilitaries was based on perpetrating massacres targeted at civilians, thought to constitute the local infrastructure of guerrillas' (Restrepo et al., 2004; Aranguren, 2001).

In October 2012, the Colombian government and FARC started peace negotiations in Havana, with the oversight of the Norwegian and Cuban government. While the four-year long process was characterized by constant ebb and flow, one of the most significant milestones was the establishment of a permanent ceasefire by FARC on December 20th, 2014. In fact, as a result of the ceasefire, FARC withdrew their troops to more remote areas where military contact with government security forces and other armed groups was unlikely to take place. Likewise, although the ceasefire involved primarily the government security forces, a clash with another armed structure, in the midst of a ceasefire, would have impacted the negotiations and the public opinion greatly. This explains why FARC's offensive activities drop by $98 \%$ during this period (CERAC, 2016). Indeed, the ceasefire was largely met until followed by the bilateral definitive ceasefire and then by the final disarmament in 2016 .

During the same period, and especially since the start of the ceasefire, the Colombian government did little to establish institutional presence in the territories that were controlled by the insurgent group (Shapiro et al., 2019). Together with FARC's inability to respond violently during the ceasefire and the fact that FARC troops stated to concentrate in a handful

\footnotetext{
${ }^{6}$ An additional small number of paramilitary groups emerged as self-defense forces, organized by rural elites to oppose guerrilla extortion.
} 
of territories that later on became the target of the reintegration programs, by and large this constituted a vacuum of power that made attractive for other armed groups (specifically the ELN and former paramilitary criminal bands) to try to establish their dominance in previously FARC-controlled territories.

3.2. Local social leaders and their targeting in Colombia. Local social leaders organize people in their communities around specific goals, helping mobilize them to demand services and redistribution from the state (such as a more equal land distribution), implement projects from the ground (such as rural roads or productive projects), oppose policies they consider harmful for the community (such as mining extraction or other potentially environmentally harmful projects), and defend human rights (for instance by denouncing violations and their perpetrators). Ultimately, leaders are responsible for coordinating communities to engage in collective activities that are thought to increase their wellbeing (CINEP, 2020; Lobo et al., 2016).

While the social identity of leaders varies widely depending on the local interests that they promote, some types or leaders are more or less likely to be victimized depending on the local political context as well as on the capacity of the state to prevent and punish violence against them. Human rights defenders in conflict-affected areas, environmental leaders in the agricultural and mining frontiers, and peasant leaders that advocate for land restitution in places that have faced high levels of dispossession or for voluntary crops's substitution in areas that are suitable to illegal crops, are some examples of the types of local leaders and why they are at risk. Social leaders constitute an obstacle for many economic and political interests, including illegal armed groups's attempts to control strategic territories. Silencing them helps thwart communities' voice and mobilization capacity.

The conditions underlying the killing of social leaders such as the opposing interests of local communities with those of outsider organizations and the low levels of state presence in large parts of the Colombian territory are not new. Indeed, the persecution of social leaders dates back at least to the emergence of the paramilitary groups, when leaders were seen as an 
instrument of the communists "subversion" (Gallón et al., 2013). Steele (2017) argues that, historically, leaders were selectively assassinated in Colombia at the same time that "regular" people were collectively displaced as complement strategies used especially by paramilitaries to facilitate territorial control.

More recently, however, the targeting of social leaders was exacerbated by the territorial dispute triggered by FARC's de facto withdrawal from its former strongholds after the start of the permanent ceasefire. ${ }^{7}$ This encouraged community leaders and activists to raise their voices to demand basic services and infrastructure from the government as they thought the conflict has ended. Formerly dispossessed peasants who fled the conflict also returned to claim their lands and re-unite with family and friends. But the central state failed to take control over these areas and brought neither development projects nor security. Instead, other armed groups stepped in to replace FARC's rule and take over its illegal activities. For the reasons described in this section, local leaders and activists constitute a threat for the interests of these groups. ${ }^{8}$

A group of leaders that has been hit by violence in a particularly high fashion are leaders of local community councils (see Table A.1.1 in the Appendix). These councils constitute the primary organizational structure of local communities in both rural hamlets and urban neighborhoods. In the former, they are the main intermediary between peasant communities and the government, and are key in helping the state implementing micro-level policies, including those agreed in the peace settlement with FARC, such as land restitution, illegal crops' substitution, and the promotion of local development initiatives. Council leaders encourage political participation, channel the demands of the community, oversee the performance of locally-elected bodies and the execution of projects, and report cases of corruption

${ }^{7}$ In recent years, almost all of the killings have taken place in the regions that FARC abandoned. See "Peacetime Spells Death for Colombia's Activists", by Nicholas Casey. Published by The New York Times on 10/13/2028. Available from: https://nyti.ms/2QQp2Rb (last accessed November 30, 2018).

${ }^{8}$ While local leaders have been sometimes accused (especially by the right and some sectors of the military) of being FARC supporters or remnants of the old FARC local governance, the legal basis of such claims is at best weak (Comisión Interamericana de derechos humanos, 2019). Instead, the stigmatization of leaders corresponds to a strategy to somehow justify their victimization. 
and criminal activity that affect the community. ${ }^{9}$

On the other hand, as suggested by Table A.1.1, leaders of the LGBT movement, leaders or students or teachers' organizations and women who are vocal of feminist movements, are targeted in much lower proportions. We hypothesize that this is mainly because of two reasons. First, the type of interests that these leaders promote are much less likely to oppose the interests of violent groups. Second, the nature of these type of movements is relatively more urban, and so these leaders are, in principle, located in environments with stronger state institutions.

\section{DATA}

4.1. Killing of social leaders. The killings of social leaders comes from a Colombian Human Right NGO called Somos Defensores. Appendix A.1.1 provides details on the primary sources and main descriptive statistics of the dataset. A social leader is defined by the NGO as an activist that represents the interests of local vulnerable communities. Social leaders include local community council members, representatives of ethnic (indigenous and AfroColombian) communities, unionists, and environmental advocates among others (Programa Somos Defensores - PNGPDDH, 2008).

Our analysis covers the period 2011:1 to 2017:2, since the start of Juan Manuel Santos' presidential term. During this period, 490 leaders were murdered (35 per semester). Before the ceasefire (until 2014:2), 250 killing cases are recorded (31 per semester). After the ceasefire there are 240 cases recorded (40 per semester). This increase can be seen in Panel A of Figure 1 , that shows the evolution of the number of leaders killed during our sample period. In turn, Figure 2 presents the spatial distribution of assassinations by municipality during the

${ }^{9}$ The Ministry of Interior estimates that the circa 64,000 local community councils in Colombia affiliate about 7 million people. Councils are present throughout the entire country except in the indigenous territories, which feature other type of organizations (albeit also targeted by armed groups seeking territorial control). See "Si no protegen a los líderes comunales el Acuerdo de Paz fracasa", La Silla Vacía, 08/13/2018. Available from: https://m.lasillavacia. com/si-no-protegen-los-lideres-comunales-el-acuerdo-de-paz-fracasa-67442?utm_source= newsletter\&utm_medium=email\&utm_campaign=Las2520cuatro2520patas2520de2520La2520Silla (last accessed November 30, 2018). 
entire period of analysis. Overall, killings are concentrated in the periphery of the country, in places relatively far from the big cities and characterized by a rather weak presence of the state. This is consistent with our interpretation that leaders are targeted in areas that are being violently disputed by armed groups after the de facto withdrawal of FARC.

4.2. Armed groups presence and exposure. Turning to our measures of armed groups presence, we use the violence dataset originally compiled by Restrepo et al. (2004), and updated through 2014 by Universidad del Rosario. This dataset codes violent events recorded in the Noche y Niebla reports from the NGO Centro de Investigación y Educación Popular (CINEP) of the Company of Jesus in Colombia, which provides a detailed description of the violent event, date, the municipality in which it occurred, the identity of the perpetrator, and the count of victims involved in the incident. ${ }^{10}$ Specifically, we create a dummy for FARC presence if there was at least one violent case by FARC in the period 2011:1-2014:2, after president Juan Manuel Santos took office and before the beginning of the ceasefire.

Measuring the influence exercised by an armed group over a specific location is extremely challenging. Indicators of presence and non-violent coercion over a large set of municipalities cannot be systematically recorded in an objective way. Violence, on the other hand, while more easily observed, is only imperfectly correlated with territorial dominance. However, non-violent dominance is unlikely to occur without any violence inflicted in the past, either as a way to legitimize influence with the citizenry or to oust any contesting (legal or illegal) group. It is thus reasonable to assume that the ability to inflict localized violence over a certain period could be expected to translate into influence in different ways. We thus follow a growing empirical literature on the Colombian conflict (see e.g. Ch et al., 2018; Acemoglu et al., 2013), and use past violence over a period of years as an (imperfect) indicator of influence. $^{11}$

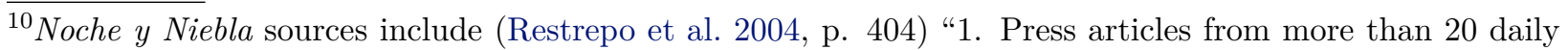
newspapers of both national and regional coverage. 2. Reports gathered directly by members of human rights NGOs and other organizations on the ground such as local public ombudsmen and, particularly, the clergy." Notably, since the Catholic Church is present in even the most remote areas of Colombia, we have extensive coverage of violent events across the entire country.

${ }^{11}$ Arjona and Otálora (2011) compare existing databases of civil war violence in Colombia to survey evidence on armed groups' presence (for the small subsample of municipalities for which the latter is available) and
} 
To measure the intention of other armed groups to dispute the control of a specific area, we follow Acemoglu et al. (2015) to create a measure of exposure to other armed groups (neo-paramilitary criminal bands and the ELN guerrilla). Appendix A.1.2 provides further details on the construction of this measure.

In Figure 2, we present the spatial distribution of armed group presence across municipalities. Municipalities marked with blue lines represent those with only FARC presence, the ones with light blue show the presence only by other armed groups, while the ones with a darker blue highlight the ones with presence of FARC and other armed groups. By comparing the left and right panels of Figure 2 it can be seen that municipalities with a darker red (higher number of assassinations) tend to be the same as the ones with darker blue (presence of FARC and other armed groups).

Finally, we split the evolution of killings by type of armed group presence since 2011. We divide the municipalities in two groups: presence of both FARC and other groups and presence of FARC only (see Figure 1 panel B). In general, we do not see any differential time pattern between these two types of municipalities before the ceasefire. However, there is a large increase in the number of killings in municipalities with presence of both FARC and other armed groups after the ceasefire. This already suggests that FARC areas exposed to the influence of other armed groups experienced an increase in killings after the ceasefire. Section 5 describes how we explore this idea more formally.

4.3. Other data. We complement these data with a large set of municipality-level characteristics from an annual panel constructed by Centro de Estudios sobre Desarrollo Económico (CEDE) at Universidad de los Andes. This dataset includes socioeconomic and geographical information for all the municipalities in Colombia. We gathered information on population, presence of coca plantations, altitude, size of the municipality, distance to the closest mayor city, tax revenue, an index for sound fiscal policy, literacy rate, and an index of rurality.

conclude that while violence is likely to underestimate -by roughly the same magnitude- both guerrilla and paramilitary control, there is a non-negligible correlation between both measures. 
Table A.3.1 of the Appendix presents summary statistics for our sample of 1,069 municipalities that includes all municipalities with a population of less than 200,000. We drop mayor cities and capitals that are mainly urban and less affected by the conflict. ${ }^{12}$ In turn, Table A.3.2 presents differences in observables between type of armed group presence at the municipality level before the ceasefire.

\section{EMPIRICAL STRATEGY}

Our identification strategy exploits the timing of the permanent ceasefire announced by FARC on December 20, 2014, during the peace negotiations with the Colombian government, and the spatial distribution of illegal armed groups in Colombia prior to the ceasefire. Since we are interested in how the killing of social leaders changed after the ceasefire in places with FARC presence that, in addition, are exposed to the influence of other armed groups, the main empirical strategy is based on a difference-in-difference-in-differences or triple differences model. ${ }^{13}$ More formally, using the subindex $m$ to denote municipalities and $t$ to denote time, we estimate:

$$
\begin{aligned}
y_{m d t}= & \alpha_{m}+\delta_{d t}+\beta_{1} \times \text { FARC }_{m} \times \text { ExposureOthers }_{m} \times \text { Cease }_{t}+\beta_{2} \times \text { FARC }_{m} \times \text { Cease }_{t} \\
& +\beta_{3} \times \text { ExposureOthers }_{m} \times \text { Cease }_{t}+\sum_{c \in \mathbf{X}_{\mathbf{m}}} \gamma^{\prime}\left(c \times \alpha_{t}\right)+\epsilon_{m d t}
\end{aligned}
$$

where $y_{m d t}$ is one of our measures of leaders killed, ${ }^{14} \mathrm{FARC}_{m}$ is a dummy that takes the value one for municipalities with FARC presence as measured before the ceasefire, and ExposureOthers $_{m}$ is our measure of exposure to other armed groups which, as explained in the previous section, comes from the interaction of a dummy of presence of other armed groups and the vector of distance-penalized vicinity. Cease $e_{t}$ is a dummy that takes the value one after the start of the permanent ceasefire, in the first semester of 2015. $\alpha_{m}$ and $\delta_{d t}$ are municipal and department-time fixed effects that capture any time-invariant municipal-level heterogeneity and any aggregate time shock at the department level, respectively. ${ }^{15}$ Given

\footnotetext{
${ }^{12} \mathrm{All}$ our results are robust to including all Colombian municipalities.

${ }^{13}$ The underlying double-differences models are not consistent with our argument, and indeed can be used as placebo exercises (see Table A.3.4 in the Appendix).

${ }^{14}$ These include the total number of killings, a dummy variable for any leader being killed in a municipality, or the rate of killings per 100,000 municipal inhabitants.

${ }^{15}$ Colombia is divided into 31 excluding the capital city and San Andrés island.
} 
that municipality characteristics are different between the ones affected and not-affected by conflict, we add municipality characteristics measured before the ceasefire $\left(X_{m}\right)$ interacted with the time fixed effects to flexibly control for differential trends parametrized by each one of the municipal attributes. Finally, the error term $\epsilon_{m d t}$ is allowed to be spatially and timely correlated, using the structure suggested by Conley (1999) and Conley (2016).

Our coefficient of interest is $\beta_{1}$ which captures the differential change in the killing of social leaders after the ceasefire in municipalities with FARC presence and that are exposed to the influence of other armed groups, relative to the change in municipalities with only FARC presence (but not exposed) or in municipalities exposed (but without FARC presence), taking into account: i) any differential effects driven by fixed municipality characteristics over time; ii) any aggregate time shock at the department level; and iii) differential municipal trends based on a large set of pre-treatment characteristics. The main identification assumption is that, in the absence of the ceasefire, the killing of social leaders in municipalities with FARC presence and exposed to other armed groups would have evolved in a similar way than the killing of leaders in other municipalities. ${ }^{16}$

\section{Results}

6.1. Main results. We start by describing, on Table 1, the empirical estimates of the main specification given by regression model 5.1. Recall that our main coefficient of interest is the (triple) interaction between a (pre-ceasefire) FARC presence indicator, the municipal "exposure" to the influence of other armed groups - given by the (distance penalized) vicinity of either neo-paramilitary criminal bands or ELN strongholds- and a dummy that captures the period after the announcement of the permanent ceasefire.

We measure the killing of social leaders in different ways. Columns 1 and 2 of Table 1 compute the rate of killings by 100,000 inhabitants (of the municipality where the death is recorded). Columns 3 and 4 use the non-normalized count of social leaders killed. Columns

\footnotetext{
${ }^{16}$ Appendix A.2.1 reports the estimating equation that is used to partially assess this "parallel trends" assumption.
} 
5 and 6 focus on the extensive margin, coding a dummy variable that takes value one if at least one single leader is killed in a municipality-year. ${ }^{17}$ While all specifications include both municipality and and time fixed effects, even columns include all the predetermined municipal controls (described in section 4) interacted with the time fixed effects to flexibly control by differential trends parametrized by each one of the municipal attributes. ${ }^{18}$

In all cases, the coefficient of interest is positive and significant. This suggests that social leaders are differentially targeted after the ceasefire in areas both formerly controlled by FARC and exposed to other armed groups. According to the magnitude of the estimate reported in Column 1, in places controlled by FARC prior to the ceasefire, a one standard deviation increase in the average municipal exposure to other armed groups (equal to 0.325, see second Panel from the top of Table A.3.1, Column 2) increases the rate of leaders killed by 0.14 per 100,000 inhabitants $(=0.418 \times 0.325)$ after the start of the permanent ceasefire. This effect is statistically significant at $5 \%$, and it implies that the pre-ceasefire mean of the social leaders' homicide more than rate doubles. Adding the differential trends parametrized by the predetermined controls, the equivalent estimated coefficient reported in Column 2 of Table 1 is slightly bigger in magnitude and implies an increase in the rate of leaders killed of 0.15 per 100,000 inhabitants $(=0.452 \times 0.325)$. It is also significant at the $5 \%$ level.

The estimate reported in Column 3 of Table 1, which focuses on the count of leaders killed, implies that in FARC-controlled areas a one standard deviation increase in the average municipal exposure to other armed groups increases the number of leaders killed by 0.03 $(=0.09 \times 0.325)$ after the ceasefire. Again, this implies that the pre-ceasefire mean of the count of leaders killed doubles. ${ }^{19}$

Finally, one potential concern given the low average of killings per semester, could be that

\footnotetext{
${ }^{17}$ This attenuates concerns about potential measurement error in the count of leaders, or the possibility that the results are driven by a higher density of social leaders in places with FARC presence and exposed to other armed groups.

${ }^{18}$ In Table A.3.3 we estimate the main regression using two alternative models that take into account the count nature of our dependent variable, namely Negative Binomial and Conditional Poisson models. In both cases we find similar results to the ones presented in Table 1.

${ }^{19}$ Allowing for differential trends parametrized by predetermined controls does not change the magnitude of the estimated coefficient substantially (see Column 4).
} 
our results are driven by a few outliers with a large number of killings in a given semester. To deal with this concern we present results on the extensive margin of killings. Column 5 implies that in places where FARC was present prior to the ceasefire a one standard deviation increase in the average municipal exposure to other armed groups increases the probability of a leader being killed in 2.1 percentage points. ${ }^{20}$ This is equivalent to an $100 \%$ increase in the probability of any leader being killed in a municipality pre-ceasefire and it is significant at the $10 \%$ level. $^{21}$

Table 1 also reveals that in municipalities exposed to the violent influence of other armed groups, but not previously controlled by FARC, there is a statistically significant drop in the killing of social leaders after the start of the permanent ceasefire. Moreover, in places dominated by FARC but not exposed to other armed groups, there is no significant differential change in the targeting of leaders. These results are consistent with our interpretation that it is the attempt at controlling territories previously dominated by FARC what drives the targeting of social leaders when the ceasefire provides the opportunity. Moreover, this evidence is also consistent with other armed groups substituting their violent effort to places formerly controlled by FARC and away from other places, after the ceasefire.

To test this more directly, in Table A.3.4 of the Appendix we present results from two difference-in-differences models, based on only the interaction between the ceasefire dummy and FARC presence (Panel A) and on the interaction between the ceasefire dummy and the exposure to other armed groups (Panel B). Consistent with our argument, we find no differential effects in municipalities previously controlled by FARC and non-robust negative relation in municipalities exposed to other armed groups. This again suggests that the main driving force for the increase in social leaders assassinations is the vacuum of power generated by the ceasefire and the exposure to other armed groups.

To partially test the identification assumption that, in the absence of the ceasefire, the killing

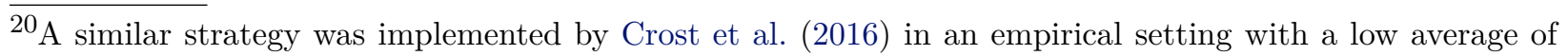
incidents per month.

${ }^{21}$ When the controls are added the estimated coefficient and the significance level remain the same (Column $6)$. 
of social leaders in municipalities with FARC presence exposed to other armed groups would have evolved in a similar way than the killing of leaders in other municipalities, and at the same time get a sense of how persistent is the differential targeting of leaders during the post ceasefire period, we present the results from estimating equation A.2.1.1. This is a non-parametric version of the main empirical specification (equation 5.1).

The results are shown in Figure A.2.1.1, where we plot the point estimates associated with the triple interaction of interest, together with the $95 \%$ confidence interval. The estimates plotted in Panel A included no controls and those of Panel B include the pre-determined controls interacted with the time fixed effects. Both cases include the municipality and time fixed effects. In neither case are there statistically significant coefficients in the years prior to the ceasefire, and the point estimates move around 0. This supports our choice of our difference-in-differences empirical strategy. However, the point estimates increase in magnitude after the start of the permanent ceasefire (with a slight decline in the last two semesters), and most of them are statistically significant.

We also conduct a more parametric test for differential trends during the pre-ceasefire period in following Muralidharan and Prakash (2017). In this test we interact a linear trend with FARC presence and other armed group exposure, FARC presence, and other armed group exposure and test for the significance of the coefficient for the triple interaction. We find no evidence of differential pre-trends (see Table A.3.5).

Finally we conduct a placebo exercise using the sign of the land agreement by FARC and the government during the peace negotiations in Havana in May 2013. ${ }^{22}$ The regressions have the same structure as the one discussed in (5.1) but instead of a Cease dummy we add a Placebo dummy which takes the value one after the first semester of 2013. In this analysis we only focus on the sample 2011:1-2014:2, as to capture pre-ceasefire effects. We find that there is no differential increase in killings of social killers after this agreement in FARC dominated areas and exposed to other armed groups (see Table A.3.6). These results

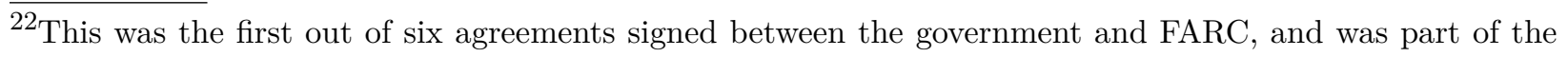
main political agenda by FARC.
} 
are consistent with the absence of differential pre-trends before the ceasefire and support the main result that most of the effect is driven by the ceasefire.

6.2. Further robustness. Our measure of exposure to the violent influence of other armed groups, based on a flexible neighborhood definition proposed by Acemoglu et al. (2015), interacts a dummy of presence of either neo-paramilitary criminal bands or the ELN guerrilla with a vector of (distance-penalized) neighboring municipalities (see section 4 for details). Thus, in our baseline measure a municipality $m$ is more or less exposed to these groups depending on whether (and how many of) its neighboring municipalities experience their presence, and on how far is the centroid of these municipalities from that of $m$ (after controlling for the average slope of the land between the two centroids).

Our results are not driven by using this specific measure of exposure. On the one hand, a simpler alternative measure defines exposure as the share of $m$ 's neighbors with presence of other armed groups. On the other hand, a more general measure does not restrict the distance-penalized indicator to m's neighbors, and instead uses all municipalities in Colombia (see Tables A.3.7 and A.3.8 in the Appendix). Overall, this is reassuring of our territorial dispute interpretation, as the surge in the killing of leaders in former FARC-dominated territories after the permanent ceasefire are driven by the exposition to other armed groups.

Our results are also not driven by lumping together neo-paramilitary criminal bands and ELN in the "other armed groups" category. These illegal armed actors have several differences, including their political objectives and their military strategy, which arguably involve different relationships with civilians. ${ }^{23}$ Importantly, however, because of the irregular nature of Colombia's internal conflict, controlling valuable municipalities is instrumental to both groups (Berman and Matanoc, 2015).

Table 2 shows the results from estimating equation 5.1, using the rate of leaders killed as dependent variable, but including in the measure of other armed groups only the neoparamilitary criminal bands (Columns 1 and 2) or only the ELN guerrilla (Columns 3 and ${ }^{23}$ Some of these differences are discussed in section 3 . 
4). ${ }^{24}$ Interestingly, FARC-dominated municipalities experience a differential surge in the rate of leaders killed after the start of the permanent ceasefire when they are exposed to the violent influence of either group, as measured separately. Moreover, in spite of the difference in the size of the reported estimated coefficients in Table 2, the economic magnitude of the effect is essentially equivalent.

Focusing on the even columns, which flexibly control for municipal-specific pre-determined characteristics, we find that in places with FARC presence prior to the ceasefire, a one standard deviation increase in the average municipal exposure to neo-paramilitary criminal bands (to the ELN) increases the rate of leaders killed by $0.364 \times 0.292=0.11(0.356 \times 0.178=0.06)$ per 100,000 inhabitants after the start of the permanent ceasefire. Recall that this effect, which in both cases is significant at conventional levels, is equivalent to doubling the rate of leaders killed relative to its pre-period mean.

Appendix A.2.3 tests if our results are exacerbated after the peace agreement between FARC and the government was signed and its implementation started at the beginning of 2017 . We reject this conjecture.

6.3. Type of targeted leaders. As discussed in section 3.2, the label 'social leader' encompasses several different type activists that represent different 'communities' and hence have different motives and work for different causes. Table A.1.1 lists the different leaders included in the Somos Defensores data, such as leaders of community councils, ethnic groups, labor unions, teachers, sexual minorities, etc. Arguably, however, not all such leaders are equally attractive as potential targets of armed groups seeking territorial control. The qualitative discussion of section 3.2, in fact, implies that a specially risky category is that of leaders of local community councils or peasants dispossessed from their land.

To investigate the effect of the ceasefire on the killing of different type of leaders, we repeat Panel B of Figure 1 by splitting the evolution of killings into four categories: leaders of local

${ }^{24}$ In Table A.3.10 we present a similar specification but where we include both neo-paramilitary and ELN interactions in the same regression. We find similar results in terms of magnitudes, while the point estimates are only marginally significant. 
community councils, leaders of peasant and conflict-related organizations, leaders of ethnic (indigenous or Afro-Colombian) communities, and a residual category of 'other' leaders. This is reported in Figure A.3.1. We note a stark increase in the killings of the first two categories (Panels A and B) right after the start of the permanent ceasefire, in places with both FARC presence and exposed to other armed groups in the pre-ceasefire period (but not in places with just FARC presence). However, we do not find a similar trend in either the category of ethnic leaders or in the residual category (Panels C and D).

A more formal test is presented on Table A.3.9 of the appendix, where we re-run the baseline empirical specification and study the effect of the ceasefire on the killing of leaders of different types, in places with both FARC presence and exposed to other armed groups. While the estimated coefficient of interest is positive throughout, it is only statistically significant (at the 5\%) for the case of local community council leaders. While this is consistent with the anecdotal discussion provided above, these results have to be interpreted with caution given that splitting the dependent variable by type of leader leaves us with very few events per category.

6.4. Potential mechanisms. We now study the potential mechanisms behind the increased targeting of leaders in former FARC strongholds exposed to other armed groups, after the start of the ceasefire. To that end we estimate heterogenous effects for a range of municipal characteristics (see section A.2.2 for more details about the implementation of these tests). Specifically, we look at three broad set of factors: the demand for land restitution, the (lack of) state capacity, and the economic attractiveness of the municipality. We also, rule out that the killing of social leaders responds to other violent dynamics that lead to indiscriminate violence in some municipalities.

6.4.1. Land restitution claims. The lack of land property rights in rural areas has been at the heart of the Colombian conflict since its initial stages (Albertus and Kaplan, 2012; Flores, 2014). Traditionally, left-wing guerrillas have been in favor of communal rural lands and the right of peasants to appropriate idle land and peripheral 'baldíos'. On the other hand, 
right-wing paramilitary groups have helped local landowners and drug lords concentrate and formalize land, often through the use of violence and intimidation (Ch et al., 2018). Indeed, most of the victims of the armed conflict (7.4 out of 8.5 million as recorded by the Unique Victims' Registry) are IDPs, and many of them were dispossessed from their land by illegal armed groups, especially the paramilitary.

Law 1448 of 2011 (known as the 'Victims and Land Restitution Law') provided the legal framework for conflict victims to obtain assistance and reparations from the government, including humanitarian aid, psychological assistance, and a large set of material reparations. This package notably includes land restitution. To facilitate the latter, the law created the Land Restitution Unit, a Presidential special unit in charge of receiving all the land restitution requests and of overseeing the subsequent judicial and administrative restitution processes. $^{25}$

Given the above discussion, we posit that the incentive of illegal armed groups to dispute the territories with prior FARC dominance following the start of the ceasefire is larger in municipalities that, since the enactment of Law 1448, have had a larger share of land claimed for restitution. In addition, we also expect that in this case the perpetrators are more likely to be neo-paramilitary criminal bands, which either directly benefited or represent groups of society who benefited from earlier land dispossession. This goes in line with some anecdotal accounts, which suggest that a non-negligible share of social leaders killed in Colombia are leaders of local community councils who specialize in mobilizing land-dispossessed victims to claim their land. ${ }^{26}$

Column 1 of Table 3 reports the estimated coefficient of the four-way interaction term described in equation A.2.2.1. In this case, the potential mechanism $Z_{m}$ is a dummy variable

\footnotetext{
${ }^{25}$ Between 2012 and 2017 over 204 thousand hectares of land had been restituted (Unidad Administrativa Especial de Gestión de Restitucioón de Tierras, 2018).

${ }^{26} \mathrm{See} " \mathrm{Si}$ no protegen a los líderes comunales el Acuerdo de Paz fracasa", La Silla Vacía, 08/13/2018. Available from: https://m.lasillavacia.com/ si-no-protegen-los-lideres-comunales-el-acuerdo-de-paz-fracasa-67442?utm_source= newsletter\&utm_medium=email\&utm_campaign=Las 2520cuatro2520patas2520de2520La2520Silla (last accessed November 30, 2018).
} 
that equals one for municipalities with land restitution claims above the median. ${ }^{27}$ We find that municipalities with FARC presence and that are exposed to other armed groups experienced a larger boost in the killing of social leaders after the start of the ceasefire if they also had a relatively large number of land restitution requests. ${ }^{28}$ Moreover, as expected, this heterogeneous effect is entirely driven by the killings perpetrated by neo-paramilitary criminal bands, and not by the ELN guerrilla. ${ }^{29}$ Again, this result suggests that other armed groups target local leaders whose activity constitutes a threat group's particular interests in a specific territory.

6.4.2. State presence. We have argued that the very nature of the peace process with FARC -that excluded other armed groups from the negotiations- constitutes a threat to the sustainability of the achieved 'peace' if not accompanied by state-led efforts to bring its capacity to the territory and consolidate its institutional presence. This argument can be extended to the degree of existing state capacity (prior to the ceasefire) in the municipalities with FARC presence. In principle, areas with existing state institutions would make it more costly for other armed groups to take control of the vacant territories by targeting the local populations.

However, it is worth noting that the concept of "state presence" encompasses different and potentially contrasting- dimensions. In the case of Colombia, with a long and welldocumented history of collusion between some factions of the military and illegal paramilitary groups (Staff et al., 1996; Romero, 2003; Dube and Naidu, 2015), military presence should be distinguished from other forms of state institutional presence, such as a strong judiciary or the existence of free and fair elections. ${ }^{30}$ Indeed, to the extent that there was at

\footnotetext{
$\overline{27}$ Specifically, we measure the intensity of the demand for land restitution using the number of requests for land restitution at the municipal level. Our dataset includes all the requests since the creation of the Land Restitution Unit until June 2015. However, our measure is only for the pre-ceasefire period.

${ }^{28}$ In our four-way interaction between FARC, other armed groups, and land restitution requests, $64 \%$ of the cases of municipalities with FARC and exposure to other armed groups have a large number of land restitution requests.

${ }^{29}$ Result available upon request.

${ }^{30}$ Paramilitary groups were first created in Colombia with the enactment of law 48 of 1968, that established protocols for the armed forces to arm and train civilians as a counter-insurgency strategy in conflict-affected
} 
least some collaboration between the military and illegal armed groups during our sample period, whereby the army protected, shared intelligence, or provided other types of support to the paramilitary, military presence could potentially exacerbate the risks faced by local leaders. $^{31}$

We explore this idea formally by testing the extent of which different measures of predetermined state capacity at the municipal level attenuate or exacerbate the targeting of social leaders by other armed groups in previously FARC-controlled areas after the start of the ceasefire. To that end, we use a measure of local judicial inefficiency (Column 2 of Table 3), electoral risk (Column 3), and the distance to the nearest military unit (Column 4) as proxies of state capacity to explore potential heterogeneous effects of our main result. ${ }^{32}$ Conceptually, both judicial inefficiency and electoral risk are proxies of lack of the type of state capacity that should mitigate the risk faced by local leaders. Municipalities with either of these characteristics are likely to engage in more monitoring and law enforcement. In contrast, as explained above, the proximity of the military could potentially be a source of empowerment for certain illegal groups.

The four-way interaction with judicial inefficiency and electoral risk measures are positive and significant, suggesting that when the local judiciary is inefficient and local electoral institutions are weak and manipulable (an inverse proxy of state capacity), illegal armed groups

areas. These organizations were then made illegal by the Constitutional Court in 1989. Some factions of the army, however, continued collaborating, now under the table, with paramilitary forces.

${ }^{31} \mathrm{As}$ an extreme case example, the Colombian armed forces have also been accused of directly perpetrating the assassination of local leaders. According to CINEP (2020), between 2016 and 201814 leaders were killed by the army and the police. As of 2020, the Inspector General's Office was investigating 18 cases involving acts of violence from government forces against local leaders (International Crisis Group, 2020). Moreover, the armed forces have also been shown to have killed hundreds of civilians when the government of President Uribe (2002-2010) provided incentives to kill or capture insurgents (Acemoglu et al., 2020).

${ }^{32}$ To measure judicial inefficiency, we follow Acemoglu et al. (2020) and use data from Colombia's Inspector General Office, the institution in charge of disciplinary oversight of all public servants. Based on an eventbased dataset with all processes arising from complaints against public servants from 1995 to 2010, we compute judicial inefficiency as the ratio between the number of complaints against judicial officials in a specific municipality and all the complaints against any public servant in that same municipality. To measure electoral risk, we use data from Misión de Observación Electoral. According to this NGO, a municipality's electoral risk is high if it experienced persistent abnormalities during the previous three elections. These include: atypical voting shares for some candidate, abnormal behavior of either void votes or unmarked ballots (over two standard deviations higher than the national mean) and an atypical turnout. 
find it easier to get away with the killing of local community leaders. ${ }^{33}$ Specifically, we find that a one standard deviation increase in the level of judicial inefficiency (0.08) increases the rate of leaders killed in $0.12(=4.932 \times 0.08 \times 0.325) .{ }^{34}$ This is equivalent to doubling the sample mean. Moreover, as in the case of land restitution we find that the effect is mainly driven by exposure to paramilitary groups, which are the ones that have been more involved in scandals related to co-opting local judges (see López 2007, Ávila and López 2010). ${ }^{35}$ Also we find that a municipality with higher electoral risk had an increased the number of killings in 1.514 cases.

In Column 4 of Table 3, we test for heterogeneous effects related to the vicinity to military units, as measured by the logarithm of the distance between the military base and the municipal centroid. ${ }^{36}$ We find that a negative and significant four-way interaction. ${ }^{37}$ This suggests that municipalities closer to a military unit experience a higher rate of leaders killed. As discussed, this is consistent with the evidence that documents illegal links between some factions of the armed forces and paramilitary groups (see Álvarez, 2015, CNMH, 2018, for additional qualitative evidence).

The validity of these results rely on two important assumptions. First, the degree of state presence was already different across FARC strongholds and the rest of the country prior to the start of the ceasefire. Second, our argument about the window of opportunity generated by the vacuum of power that followed the ceasefire assumes that state capacity did not differentially change after the ceasefire in both types of municipalities. The latter point is important because it also rules out a potential strategic behavior of the government whereby state presence is reduced in former FARC strongholds as a way to facilitate the arrival of

\footnotetext{
${ }^{33}$ Acemoglu et al. (2020) show that one source of local judicial inefficiency is the capture by groups with de facto political power to get away with unlawful behavior.

${ }^{34}$ In our four-way interaction between FARC, other armed groups, and judicial inefficiency, $70 \%$ of the cases of municipalities with FARC and exposure to other armed groups have judicial inefficiency.

${ }^{35}$ Results available upon request.

${ }^{36} \mathrm{~A}$ military unit is defined as a brigade headquarter, which includes several battalions, and it can have from 500 to 5,000 soldiers.

${ }^{37}$ In our four-way interaction between FARC, other armed groups, and military presence, $72 \%$ of the cases of municipalities with FARC and exposure to other armed groups have military presence.
} 
illegal groups and the elimination of some forms of community collective action.

Tables A.3.11 and A.3.12 of the Appendix suggest that both of these assumptions are plausible. First, Table A.3.11 shows that, prior to the start of the ceasefire, municipalities with FARC presence had higher judicial inefficiency and electoral risk, as well as lower administrative and fiscal capacity (in the form of per capita tax revenues, expenditures and the reception of transfers from the central government). Second, Table A.3.12 uses the proxies of state capacity for which we have enough time variation and documents that neither proxy changes significantly in FARC-affected areas, relative to other municipalities, after the start of the ceasefire.

6.4.3. Economic incentives. Third, to test for differential effects based on the availability (or potential) of illegal rents, we add estimate a heterogeneous effect based on the coca suitability of each municipality (see Mejía and Restrepo 2015). ${ }^{38}$ As reported on Column 5 of Table 3, we do not find that more leaders are killed in places with higher coca suitability. ${ }^{39}$ Moreover, this no-result is robust to measuring coca with actual coca availability (the share of municipal land cultivated with coca) or the availability of (legal or illegal) natural-resource mines. Overall our results do not support the idea that the economic value of municipalities exacerbate the killing of social leaders.

6.4.4. Indiscriminate violence as an alternative explanation. As a final attempt to identify the potential mechanism explaining our main result we investigate the effect of the ceasefire on the aggregate homicide rate of municipalities. Our story requires that the killing of social leaders is driven by the selective targeting of leaders so as to thwart collective action at the local level, and not by indiscriminate municipal violence. To rule out that our results are explained by an aggregate increase in insecurity in FARC-dominated territories exposed to other armed groups after the ceasefire, that mechanically translates into more leaders killed, Table 4 estimates equation 5.1 using as dependent variable the overall municipal homicide

\footnotetext{
${ }^{38}$ Prem et al. (2021a) show that after a naive policy announcement about crop substitution in 2014 there was an increase in coca cultivation in areas with more coca suitability.

${ }^{39}$ In our four-way interaction between FARC, other armed groups, and coca suitability, $70 \%$ of the cases of municipalities with FARC and exposure to other armed groups have high coca suitability.
} 
rate. The coefficient of interest, associated with the triple interaction, is not statistically significant. This is reassuring that social leaders are being selectively targeted by other armed groups.

\section{Conclusions}

Territorial contestation by armed groups in the context of civil war often involves the selective killing of civilians. This strategy, which has been documented by a vast literature in political science, is used to encourage allegiance, as well as to achieve informal collaboration, prevent defections, mobilize supporters, and increase military strength. In this paper, we posit that peace agreements may trigger territorial disputes and thus the selective targeting of civilians if two key conditions are present. First, not all the active armed groups are included in the peacemaking efforts. Second, the legitimate government fails to establish key components of state presence in the areas formerly controlled by the groups who participate in the agreement. That these two conditions can ignite selective violence against civilians is consistent with the post-agreements dynamics of countries such as Guatemala, Nepal, and Sierra Leone.

We test the conjecture formally by leveraging the subnational longitudinal variation provided by the recent peace process in Colombia between the FARC insurgency and the central government. Our estimation strategy exploits the temporal variation given by the ceasefire as well as the cross-sectional variation given by the presence of FARC and the exposure to the influence of other armed groups. We do so in a triple differences model that controls for two-way fixed effects and for differential trends parametrized by a large set of pre-determined municipal controls.

We show that the recent surge in the systematic killing of local social leaders in Colombia can be -at least partially- explained by the vacuum of power that FARC's permanent ceasefire left in this group's controlled areas, which encouraged other illegal armed groups seeking to occupy these areas to target local community leaders. Our results are not explained by the 
overall municipal homicide rate which suggests that they are not caused by either a differential change in reporting after the ceasefire or by a strategy of indiscriminate violence against civilians. In addition, we show that the killing of leaders is exacerbated in areas with high demand for land restitution and a weaker state capacity in the form of an inefficient local judiciary and high electoral risk.

Overall, the selective killing of civilians, we argue, constitutes an unintended negative consequence of a partial pacification process that was not accompanied by an effort to consolidate the control of the territory by the legitimate state. In the case of Colombia, despite the historical importance and the tremendous opportunity of the peace agreement with the FARC, the recent surge in the killing of social leaders may be the beginning of a new and more sophisticated stage of social disruption. We hope to be wrong.

\section{REFERENCES}

Acemoglu, D., L. Fergusson, J. Robinson, D. Romero, and J. F. Vargas (2020): "The perils of highpowered incentives: evidence from Colombia's false positives," American Economic Journal: Economic Policy, 12, 1-43.

Acemoglu, D., C. Garcia-Jimeno, and J. A. Robinson (2015): "State capacity and economic development: A network approach," American Economic Review, 105, 2364-2409.

Acemoglu, D., J. A. Robinson, and R. J. Santos (2013): "The monopoly of violence: Evidence from colombia," Journal of the European Economic Association, 11, 5-44.

Albertus, M. And O. Kaplan (2012): "Land Reform as a Counterinsurgency Policy," Journal of Conflict Resolution, 57, 198-231.

Alesina, A., S. Piccolo, And P. Pinotti (2019): "Organized Crime, Violence, and Politics," Review of Economic Studies, 86, 457-499.

Álvarez, S. M. (2015): "Paramilitares, Fuerza Pública y periferias amenazantes," Boletín Cultural y Bibliográfico, 49, 106-107.

Aranguren, M. (2001): Mi Confesión: Carlos Castaño Revela sus Secretos, Oveja Negra.

ArJona, A. (2016): Rebelocracy: Social Order in the Colombian Civil War, Cambridge Studies in Comparative Politics, Cambridge University Press.

Arjona, A. M. and L. OtÁlora (2011): "Presencia vs. violencia: problemas de medición de la presencia de actores armados en Colombia," Foco Económico. 
Ávila, A. F. AND C. N. LóPEZ (2010): Y refundaron la patria-: de cómo mafiosos y políticos reconfiguraron el estado colombiano, Debate.

Balcells, L. (2017): Rivalry and revenge, Cambridge University Press.

Berman, E., J. Felter, J. Shapiro, and E. Troland (2013): "Modest, Secure, and Informed: Successful Development in Conflict Zones," American Economic Review, 103, 512-517.

Berman, E. And A. Matanoc (2015): "The Empiricists' Insurgency," Annual Review of Political Science, $18,443-464$.

Berman, E., J. N. Shapiro, and J. H. Felter (2011): "Can hearts and minds be bought? The economics of counterinsurgency in Iraq," Journal of Political Economy, 119, 766-819.

Blattman, C. And J. Annan (2016): "Can employment reduce lawlessness and rebellion? A field experiment with high-risk men in a fragile state," American Political Science Review, 110, 1-17.

Carter, D. B., A. Shaver, and A. Wright (2019): "Places to Hide: Terrain, Ethnicity, and Political Violence," Journal of Politics, 81, 1446-1465.

CERAC (2016): "Un año de desescalamiento: conflicto casi detenido, pero que se resiste a desaparecer," 12.

Ch, R., A. Steele, J. Shapiro, and J. Vargas (2018): "Endogenous taxation in ongoing internal conflict: The case of Colombia," American Political Science Review, 112, 996-1015.

Christia, F. (2012): Alliance formation in civil wars, Cambridge University Press.

CINEP (2020): ¿¿CUÁLES SON LOS PATRONES? Asesinatos de Líderes Sociales en el Post Acuerdo,” Tech. rep., Ascamcat, CINEP/PPP, Comisión Colombiana de Juristas (CCJ), Confederación Acción Comuna, Coordinación Colombia Estados Unidos, Instituto de Estudios Políticos y Relaciones Internacionales (IEPRI), Movimiento Ríos vivos, Somos defensores, Universidad Nacional de Colombia.

Clutterbuck, R. (1966): The Long, Long War: Counterinsurgency in Malaya and Vietnam., Praeger.

CNMH (2018): "Conversaciones inéditas entre la Fuerza Pública y el Centro Nacional de Memoria Histórica: aprendizajes de una experiencia (2012-2017)," .

Comisión Interamericana de Derechos humanos (2019): "Informe sobre la situación de personas defensoras de derechos humanos y líderes sociales en Colombia:," Tech. rep.

Condra, L. And J. Shapiro (2012): "Who Takes the Blame? The Strategic Effects of Collateral Damage," American Journal of Political Science, 56, 167-187.

Conley, T. G. (1999): "GMM estimation with cross sectional dependence," Journal of Econometrics, 92, $1-45$.

(2016): Spatial Econometrics, London: Palgrave Macmillan UK, 1-9.

Crost, B., J. H. Felter, And P. B. Johnston (2016): "Conditional cash transfers, civil conflict and insurgent influence: Experimental evidence from the Philippines," Journal of Development Economics, 
$118,171-182$.

De la CAlle, L. (2017): "Compliance vs. constraints: A theory of rebel targeting in civil war," Journal of Peace Research, 54, 427-441.

Dell, M. (2015): "Trafficking networks and the Mexican drug war," American Economic Review, 105, 1738-79.

Derouen Jr, K., M. J. Ferguson, S. Norton, Y. H. Park, J. Lea, and A. Streat-Bartlett (2010): "Civil war peace agreement implementation and state capacity," Journal of Peace Research, 47, $333-346$.

Downes, A. (2007): "Restraint or Propellant? Democracy and Civilian Fatalities in Interstate Wars," Journal of Conflict Resolution, 51, 872-904.

Doyle, M. W. And N. Sambanis (2000): "International peacebuilding: A theoretical and quantitative analysis," American Political Science Review, 94, 779-801.

Dube, O. And S. Naidu (2015): "Bases, Bullets, and Ballots: The Effect of US Military Aid on Political Conflict in Colombia," Journal of Politics, 77, 249-267.

Dube, O. And J. F. VArgas (2013): "Commodity price shocks and civil conflict: Evidence from Colombia," The Review of Economic Studies, 80, 1384-1421.

Eck, K. And L. Hultman (2007): "One-sided violence against civilians in war: Insights from new fatality data," Journal of Peace Research, 44, 233-246.

Fearon, J., M. Humphreys, And J. Weinstein (2009): "Modest, Secure, and Informed: Successful Development in Conflict Zones," American Economic Review, 99, 287-291.

Fearon, J. D. And D. D. Laitin (2003): "Ethnicity, Insurgency, and Civil War," American Political Science Review, 97, 75-90.

Flores, T. (2014): "Vertical Inequality, Land Reform, and Insurgency in Colombia," Peace Economics, Peace Science, and Public Policy, 20, 5-31.

Franke, J. AND T. Öztürk (2015): "Conflict networks," Journal of Public Economics, 126, 104-113.

Gallón, G., H. Rodríguez, And D. F. Abonía (2013): "Desafiando la intransigencia," .

Galula, D. (1964): Counterinsurgency Warfare; Theory and Practice, New York: Praeger.

Goodwin, J. (2001): No Other Way Out: States and Revolutionary Movements 1945-1991, Cambridge University Press.

Guerra-Cújar, M. E., M. Prem, P. Rodríguez-Lesmes, and J. F. Vargas (2020): “The Peace Baby Boom: Evidence from Colombia's peace agreement with FARC," Documentos de Trabajo.

Hartman, A. C., R. A. Blair, and C. Blattman (2021): "Engineering informal institutions: Long-run impacts of alternative dispute resolution on violence and property rights in Liberia," Tech. Rep. 1. 
Hoddie, M. AND C. A. HARTZELl (2010): Strengthening peace in post-civil war states: Transforming spoilers into stakeholders, University of Chicago Press.

HubER, L. (2019): "When civilians are attacked: gender equality and terrorist targeting," Journal of Conflict Resolution, 63, 2289-2318.

Human Rights Watch (2021): “Left Undefended: Killings of Rights Defenders in Colombia's Remote Communities," Tech. rep., Human Rights Watch.

Humpreys, M. And J. Weinstein (2006): "Handling and Manhandling Civilians in Civil War," American Political Science Review, 100, 429-447.

International Crisis Group (2020): "Leaders under Fire: Defending Colombia's Front Line of Peace," Tech. rep., International Crisis Group.

Kalyvas, S. And M. Kocher (2007): "How "Fre" Is Free Riding in Civil Wars? Violence, Insurgency, and the Collective Action Problem," World Politics, 59, 177-216.

Kalyvas, S. N. (2006): The Logic of Violence in Civil War, Cambridge Studies in Comparative Politics, Cambridge University Press.

Kocher, M., T. Pepinsky, and S. Kalyvas (2011): "Aerial Bombing and Counterinsurgency in the Vietnam War," American Political Science Review, 55, 201-218.

König, M. D., D. Rohner, M. Thoenig, And F. Zilibotti (2017): "Networks in conflict: Theory and evidence from the great war of africa," Econometrica, 85, 1093-1132.

LE Billon, P. (2012): “Bankrupting peace spoilers: Can peacekeepers curtail belligerents' access to resource revenues?" in High-value natural resources and post-conflict peacebuilding, Routledge, 41-64.

Lobo, I., M. VÉLEz, And S. Puerto (2016): "Leadership, entrepreneurship and collective action: A case study from the Colombian Pacific region," International Journal of the Commons, 10.

López, C. (2007): "La ruta de la expansión paramilitar y la transformación política de Antioquia," Para política: la ruta de la expansión paramilitar y los acuerdos políticos, Corporación Nuevo Arco Iris, Bogotá.

LYALL, J. (2009): "Does Indiscriminate Violence Incite Insurgent Attacks?Evidence from Chechnya," Journal of Conflict Resolution, 53, 331-362.

— (2019): "Civilian Casualties, Humanitarian Aid, and Insurgent Violence in Civil Wars," International Organization, 73, 901-926.

Lyall, J., G. Blair, And K. Imai (2013): "Explaining Support for Combatants during Wartime: A Survey Experiment in Afghanistan," American Political Science Review, 107, 679-705.

Mason, D. And D. Krane (1989): "The Political Economy of Death Squads: Toward a Theory of the Impact of State-Sanctioned Terror," International Studies Quarterly, 33, 175-198. 
MejíA, D. And P. Restrepo (2015): "Bushes and Bullets: Illegal Cocaine Markets and Violence in Colombia." .

Mueller, H., D. Rohner, And D. Schönholzer (2019): "The Peace Dividend of Distance: Violence as Interaction Across Space," unpublished manuscript.

Muralidharan, K. And N. Prakash (2017): "Cycling to school: Increasing secondary school enrollment for girls in India," American Economic Journal: Applied Economics, 9, 321-50.

Newman, E., O. Richmond, K. Aggestam, M.-J. Zahar, E. Stepanova, Y. Shain, R. Aryasinha, R. MacGinty, D. Conversi, V. Bojicic-Dzelilovic, ET Al. (2006): Challenges to peacebuilding: Managing spoilers during conflict resolution, United Nations University Press.

Petersen, R. D. (2001): Resistance and rebellion: lessons from Eastern Europe, Cambridge University Press.

Prem, M., S. SaAvedra, And J. F. VArgas (2020): "End-of-conflict deforestation: Evidence from Colombia's peace agreement," World Development, 129, 104852.

Prem, M., J. VArgas, And D. Mejía (2021a): "The rise and persistence of illegal crops: Evidence from a naive policy announcement," The Review of Economics and Statistics.

Prem, M., J. F. VArgas, And O. NAmen (2021b): "The Human Capital Peace Dividend," The Journal of Human Resources.

Programa Somos Defensores - PNGPDDH (2008): "Defender y Proteger la Vida: La Acciión de los Defensores de Derechos Humanos en Colombia," .

Regan, P. M. (2014): "Bringing peace back in: Presidential address to the Peace Science Society, 2013," Conflict Management and Peace Science, 31, 345-356.

Restrepo, J., M. Spagat, And J. Vargas (2004): "The dynamics of the columbian civil conflict: A new dataset." Homo Oeconomicus, 21, 396-429.

Richani, N. (1997): "The Political Economy of Violence: The War-System in Colombia." Journal of Interamerican Studies and World Affairs, 39, 37-81.

Robinson, T. And R. Torvik (2009): "Vertical Inequality, Land Reform, and Insurgency in Colombia," American Ecnomic Review, 99, 310-315.

Romero, M. (2003): Paramilitares y autodefensas, Bogotá: IEPRI-Planeta.

Schwartz, R. A. And S. Straus (2018): "What drives violence against civilians in civil war? Evidence from Guatemala's conflict archives," Journal of Peace Research, 55, 222-235.

Shapiro, J., A. Steele, And J. Vargas (2019): "State-building at the Community Level: Evaluating the Impact of Colombia's Consolidation Program," Unpublished manuscript. 
Shaver, A., J. Shapiro, ET AL. (2016): "The effect of civilian casualties on wartime informing: Evidence from the Iraq war," Journal of Conflict Resolution.

Staff, H. R. W., H. R. Watch/Americas, and A. P. H. R. Watch) (1996): Colombia's Killer Networks: The Military-Paramilitary Partnership and the United States, Human Rights Watch.

Stedman, S. J. (1997): "Spoiler problems in peace processes," International security, 22, 5-53. (2003): "Peace processes and the challenges of violence," in Contemporary Peacemaking, Springer, $103-113$.

Steele, A. (2017): Democracy and Displacement in Colombia's Civil War, Cornell University Press.

TAydas, Z. And D. Peksen (2012): "Can states buy peace? Social welfare spending and civil conflicts," Journal of Peace Research, 49, 273-287.

Thompson, R. (1966): Defeating Communist Insurgency: The Lessons of Malaya and Vietnam., Praeger.

Toft, M. And Y. Zhukov (2015): "Islamists and Nationalists: Rebel Motivation and Counterinsurgency in Russia's North Caucasus," American Political Science Review, 109, 222-238.

Unidad Administrativa Especial de Gestión de Restitucioón de Tierras (2018): "Informe Preliminar a la Audiencia Pública de Rendición de Cuentas: Vigencia 2017," .

VArgas, J. (2016): Strategic Atrocities Civilians under Crossfire: Theory and Evidence from Colombia, Oxford University Press, 425-451.

Werb, D., G. Rowell, G. Guyatt, T. Kerr, J. Montaner, and E. Wood (2011): "Effect of drug law enforcement on drug market violence: A systematic review," International Journal of Drug Policy, $22,87-94$.

Wood, R. M. (2010): "Rebel capability and strategic violence against civilians," Journal of Peace Research, $47,601-614$. 


\section{FIGURE 1. Evolution of social leaders killings}

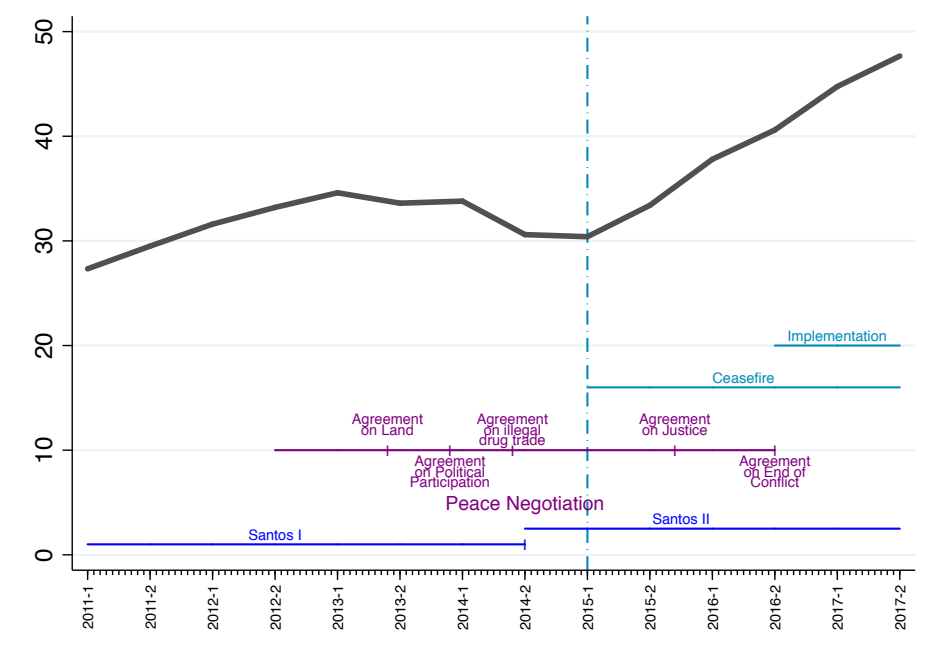

A. Aggregate

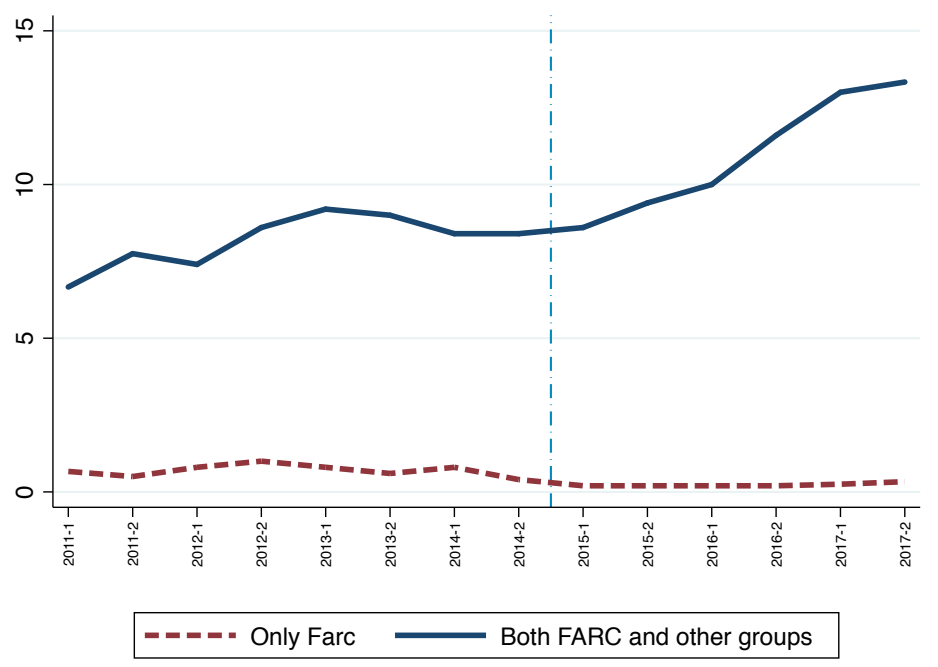

B. Split by type of municipality

Notes: This figure presents the evolution of killings of social leaders from 2010 to 2017. Panel A presents the distribution of total cases per semester and adds the description of the peace process. In panel B we split the sample by type of municipality, distinguishing between municipalities with FARC presence and above the median of exposure to other armed groups and municipalities with FARC presence but not exposed. In both panels we show one-year moving averages to smooth the data. 


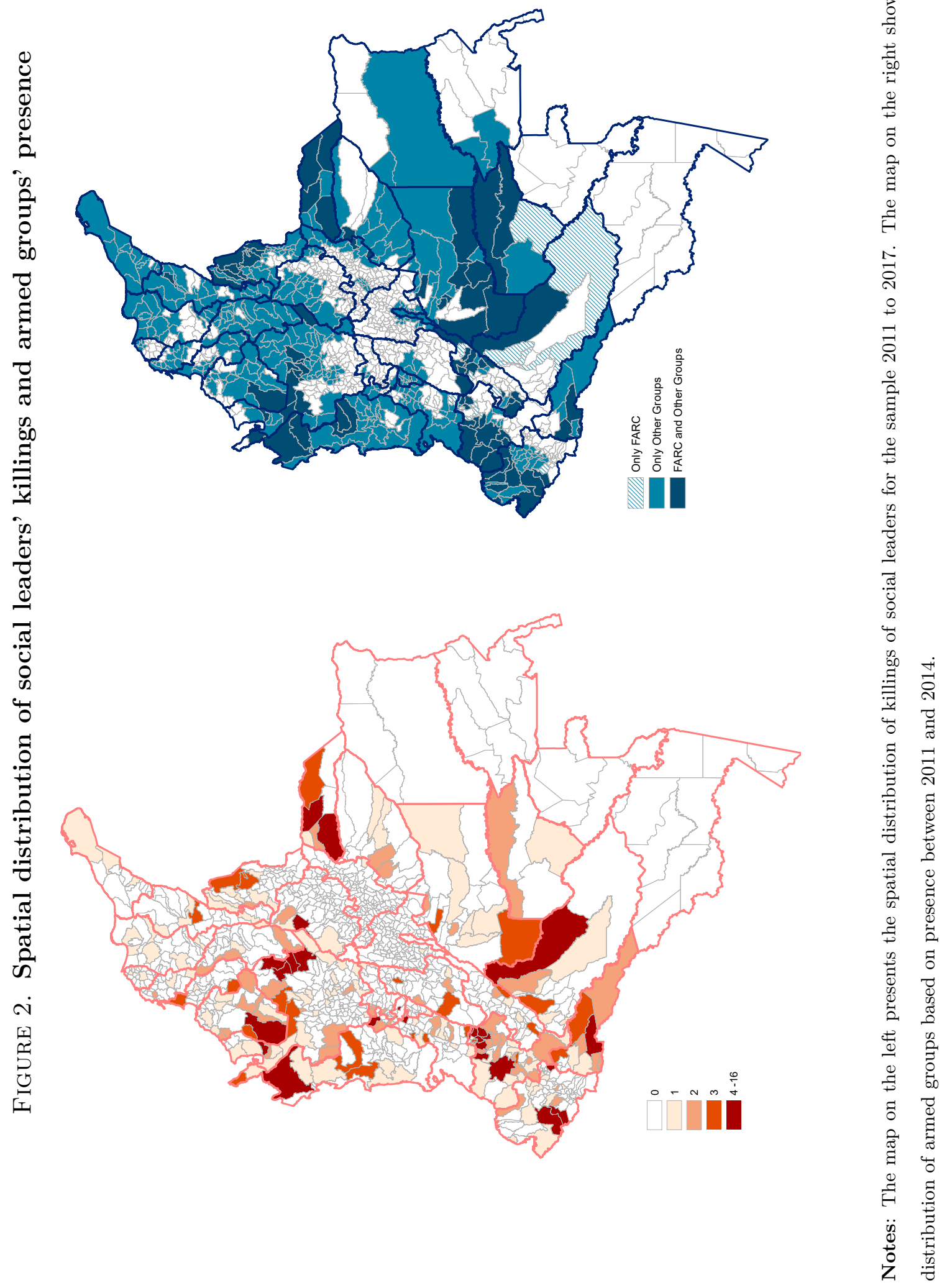


TABLE 1. Killing of social leaders, FARC presence, and exposure to other armed groups

\begin{tabular}{|c|c|c|c|c|c|c|}
\hline & \multicolumn{2}{|c|}{ Killing rate } & \multicolumn{2}{|c|}{ Number of killings } & \multicolumn{2}{|c|}{ Any killing } \\
\hline & (1) & (2) & (3) & (4) & (5) & (6) \\
\hline Cease $\times$ FARC $\times$ ExposureOthers & $\begin{array}{l}0.418^{* *} \\
(0.183)\end{array}$ & $\begin{array}{l}0.452^{* *} \\
(0.188)\end{array}$ & $\begin{array}{l}0.106^{* *} \\
(0.044)\end{array}$ & $\begin{array}{l}0.111^{* *} \\
(0.044)\end{array}$ & $\begin{array}{c}0.065^{*} \\
(0.035)\end{array}$ & $\begin{array}{c}0.068^{*} \\
(0.035)\end{array}$ \\
\hline Cease $\times$ FARC & $\begin{array}{l}-0.137 \\
(0.107)\end{array}$ & $\begin{array}{l}-0.132 \\
(0.114)\end{array}$ & $\begin{array}{l}-0.021 \\
(0.018)\end{array}$ & $\begin{array}{l}-0.024 \\
(0.019)\end{array}$ & $\begin{array}{l}-0.007 \\
(0.016)\end{array}$ & $\begin{array}{l}-0.011 \\
(0.017)\end{array}$ \\
\hline Cease $\times$ ExposureOthers & $\begin{array}{c}-0.255^{* * *} \\
(0.095)\end{array}$ & $\begin{array}{c}-0.279^{* * *} \\
(0.099)\end{array}$ & $\begin{array}{c}-0.036^{* * *} \\
(0.013)\end{array}$ & $\begin{array}{c}-0.041^{* * *} \\
(0.014)\end{array}$ & $\begin{array}{c}-0.026^{* *} \\
(0.011)\end{array}$ & $\begin{array}{c}-0.031^{* * *} \\
(0.011)\end{array}$ \\
\hline Observations & 14966 & 14966 & 14966 & 14966 & 14966 & 14966 \\
\hline Municipalities & 1069 & 1069 & 1069 & 1069 & 1069 & 1069 \\
\hline Municipality FE & $\checkmark$ & $\checkmark$ & $\checkmark$ & $\checkmark$ & $\checkmark$ & $\checkmark$ \\
\hline Department-Period FE & $\checkmark$ & $\checkmark$ & $\checkmark$ & $\checkmark$ & $\checkmark$ & $\checkmark$ \\
\hline Controls & & $\checkmark$ & & $\checkmark$ & & $\checkmark$ \\
\hline Avg Dep Var & 0.101 & 0.101 & 0.028 & 0.028 & 0.021 & 0.021 \\
\hline SD Dep Var & 1.083 & 1.083 & 0.219 & 0.219 & 0.144 & 0.144 \\
\hline
\end{tabular}

Notes: This table presents the results from the main specification in equation (5.1). We exploit municipallevel variation by semester, over the period 2011:1 to 2017:2. Columns (1) and (2) use the number of homicides of social leaders over total population, columns (3) and (4) use as dependent variable the total number of homicides of social leaders, while columns (5) and (6) use a dummy that takes the value one if there was at least one social leader assassinated. Cease is a dummy that takes the value one for the period after 2015:1. FARC is a dummy for those municipalities with FARC presence. ExposureOthers is a continuous variable that measures ELN or paramilitary groups presence in the municipality or their (distance-penalized) vicinity. Predetermined municipal controls includes logarithm of the population in 2010, municipality area, average elevation, distance to the closest major city, share of population under poverty, literacy rate, math and language test scores, index of rurality, log of tax income and index of good fiscal policy. Errors in parentheses control for spatial and first-order time correlation (see Conley, 1999, Conley, 2016). We allow spatial correlation to extend to up to $279 \mathrm{~km}$ from each municipality's centroid to ensure that each municipality has at least one neighbor. $*$ is significant at the $10 \%$ level, $* *$ is significant at the $5 \%$ level, *** is significant at the $1 \%$ level. 
TABLE 2. Killing of social leaders by exposure to different armed groups

\begin{tabular}{|c|c|c|c|c|}
\hline & \multicolumn{2}{|c|}{ Neo-Paramilitary } & \multicolumn{2}{|c|}{ ELN } \\
\hline & (1) & $(2)$ & $(3)$ & $(4)$ \\
\hline Cease $\times$ FARC $\times$ ExposureOthers & $\begin{array}{c}0.369^{*} \\
(0.204)\end{array}$ & $\begin{array}{c}0.403^{* *} \\
(0.206)\end{array}$ & $\begin{array}{c}0.403^{* *} \\
(0.198)\end{array}$ & $\begin{array}{c}0.449^{* *} \\
(0.199)\end{array}$ \\
\hline Cease $\times$ FARC & $\begin{array}{l}-0.101 \\
(0.101)\end{array}$ & $\begin{array}{l}-0.132 \\
(0.107)\end{array}$ & $\begin{array}{c}-0.076 \\
(0.091)\end{array}$ & $\begin{array}{l}-0.061 \\
(0.100)\end{array}$ \\
\hline Cease $\times$ ExposureOthers & $\begin{array}{c}-0.244^{* *} \\
(0.113)\end{array}$ & $\begin{array}{c}-0.263^{* *} \\
(0.118)\end{array}$ & $\begin{array}{c}-0.239^{* *} \\
(0.098)\end{array}$ & $\begin{array}{c}-0.250^{* * *} \\
(0.096)\end{array}$ \\
\hline Observations & 14966 & 14966 & 14966 & 14966 \\
\hline Municipalities & 1069 & 1069 & 1069 & 1069 \\
\hline Municipality FE & $\checkmark$ & $\checkmark$ & $\checkmark$ & $\checkmark$ \\
\hline Department-Period FE & $\checkmark$ & $\checkmark$ & $\checkmark$ & $\checkmark$ \\
\hline Controls & & $\checkmark$ & & $\checkmark$ \\
\hline Avg Dep Var & 0.101 & 0.101 & 0.101 & 0.101 \\
\hline SD Dep Var & 1.083 & 1.083 & 1.083 & 1.083 \\
\hline
\end{tabular}

Notes: This table presents the results from the main specification in equation (5.1). The dependent variable is the number of homicides of social leaders over total population. In columns (1) and (2) ExposureOthers is a continuous variable that measures paramilitary groups presence in the municipality or their (distance-penalized) vicinity, while in columns (3) and (4) is a continuous variable that measures ELN presence. See Table 1 for more details on variables definition, predetermined controls, and standard errors. ${ }^{*}$ is significant at the $10 \%$ level, ${ }^{* *}$ is significant at the $5 \%$ level, ${ }^{* * *}$ is significant at the $1 \%$ level. 
TABLE 3. Heterogeneous effects by municipality characteristics

\begin{tabular}{|c|c|c|c|c|c|}
\hline & $\begin{array}{c}\text { Land } \\
\text { Restitution }\end{array}$ & $\begin{array}{c}\text { Judicial } \\
\text { Inefficiency }\end{array}$ & $\begin{array}{l}\text { Electoral } \\
\text { Risk }\end{array}$ & $\begin{array}{l}\text { Military } \\
\text { Presence }\end{array}$ & $\begin{array}{c}\text { Coca } \\
\text { Suitability }\end{array}$ \\
\hline & (1) & $(2)$ & (3) & (4) & $(5)$ \\
\hline Cease $\times$ FARC $\times$ ExposureOthers $\times \mathrm{Z}$ & $\begin{array}{l}0.746^{*} \\
(0.386)\end{array}$ & $\begin{array}{l}5.169^{* *} \\
(2.309)\end{array}$ & $\begin{array}{l}1.523^{* *} \\
(0.619)\end{array}$ & $\begin{array}{c}-0.276^{*} \\
(0.141)\end{array}$ & $\begin{array}{c}0.238 \\
(0.417)\end{array}$ \\
\hline Cease $\times$ FARC $\times \mathrm{Z}$ & $\begin{array}{l}-0.049 \\
(0.210)\end{array}$ & $\begin{array}{r}-0.110 \\
(0.691)\end{array}$ & $\begin{array}{c}-0.491^{*} \\
(0.280)\end{array}$ & $\begin{array}{l}0.205^{* *} \\
(0.102)\end{array}$ & $\begin{array}{c}0.277 \\
(0.368)\end{array}$ \\
\hline Cease $\times$ ExposureOthers $\times Z$ & $\begin{array}{l}-0.151 \\
(0.197)\end{array}$ & $\begin{array}{l}-1.396 \\
(0.887)\end{array}$ & $\begin{array}{l}-0.412 \\
(0.470)\end{array}$ & $\begin{array}{c}0.032 \\
(0.046)\end{array}$ & $\begin{array}{c}-0.356^{* *} \\
(0.169)\end{array}$ \\
\hline Cease $\times$ FARC $\times$ ExposureOthers & $\begin{array}{c}0.001 \\
(0.304)\end{array}$ & $\begin{array}{l}-0.001 \\
(0.259)\end{array}$ & $\begin{array}{c}0.250 \\
(0.177)\end{array}$ & $\begin{array}{c}0.497^{* * *} \\
(0.188)\end{array}$ & $\begin{array}{c}0.392 \\
(0.312)\end{array}$ \\
\hline Cease $\times$ FARC & $\begin{array}{l}-0.113 \\
(0.130)\end{array}$ & $\begin{array}{l}-0.130 \\
(0.140)\end{array}$ & $\begin{array}{l}-0.041 \\
(0.129)\end{array}$ & $\begin{array}{l}-0.150 \\
(0.111)\end{array}$ & $\begin{array}{l}-0.359 \\
(0.341)\end{array}$ \\
\hline Cease $\times$ ExposureOthers & $\begin{array}{l}-0.200 \\
(0.178)\end{array}$ & $\begin{array}{c}-0.189^{* *} \\
(0.093)\end{array}$ & $\begin{array}{c}-0.212^{* * *} \\
(0.068)\end{array}$ & $\begin{array}{c}-0.281^{* * *} \\
(0.098)\end{array}$ & $\begin{array}{l}-0.102 \\
(0.079)\end{array}$ \\
\hline Cease $\times \mathrm{Z}$ & $\begin{array}{c}0.056 \\
(0.041)\end{array}$ & $\begin{array}{c}0.092 \\
(0.132)\end{array}$ & $\begin{array}{c}-0.077^{*} \\
(0.043)\end{array}$ & $\begin{array}{l}-0.018 \\
(0.019)\end{array}$ & $\begin{array}{l}-0.036 \\
(0.036)\end{array}$ \\
\hline Observations & 14966 & 14966 & 14966 & 14966 & 14966 \\
\hline Municipalities & 1069 & 1069 & 1069 & 1069 & 1069 \\
\hline Municipality FE & $\checkmark$ & $\checkmark$ & $\checkmark$ & $\checkmark$ & $\checkmark$ \\
\hline Department-Period FE & $\checkmark$ & $\checkmark$ & $\checkmark$ & $\checkmark$ & $\checkmark$ \\
\hline Controls & $\checkmark$ & $\checkmark$ & $\checkmark$ & $\checkmark$ & $\checkmark$ \\
\hline Avg Dep Var & 0.101 & 0.101 & 0.101 & 0.101 & 0.101 \\
\hline SD Dep Var & 1.083 & 1.083 & 1.083 & 1.083 & 1.083 \\
\hline
\end{tabular}

Notes: This table presents the results from the main specification in equation (A.2.2.1). The dependent variable is the number of homicides of social leaders over total population. Land restitution is a dummy for those municipalities with the number of request for land restitution over the size of the municipality being above the median. Judicial inefficiency is the share of justice employees under disciplinary investigations. Electoral Risk is a dummy that takes the value of one if the municipality had abnormal behavior during the previous three congressional elections. Military presence is the logarithm of the distance to the closest military unit. Coca suitability is a dummy that takes the value one if the index for coca suitability from Mejía and Restrepo (2015) is above the median of the empirical distribution weighted by the exposure to coca plantations in neighboring municipalities. See Table 1 for more details on variables definition, predetermined controls, and standard errors. ${ }^{*}$ is significant at the $10 \%$ level, $* *$ is significant at the $5 \%$ level, $* * *$ is significant at the $1 \%$ level. 
TABLE 4. Overall homicides rate, FARC presence, and exposure to other armed groups

\begin{tabular}{lcc}
\hline \hline & \multicolumn{2}{c}{ Homicide rate } \\
\cline { 2 - 3 } & $(1)$ & $(2)$ \\
& & \\
Cease $\times$ FARC $\times$ ExposureOthers & 4.787 & 4.221 \\
& $(3.825)$ & $(3.635)$ \\
Cease $\times$ FARC & -2.084 & -1.568 \\
& $(2.177)$ & $(2.230)$ \\
Cease $\times$ ExposureOthers & $-3.688^{* *}$ & $-4.210^{* * *}$ \\
& $(1.521)$ & $(1.526)$ \\
Observations & & \\
Municipalities & 14966 & 14966 \\
Municipality FE & 1069 & 1069 \\
Department-Period FE & $\checkmark$ & $\checkmark$ \\
Controls & $\checkmark$ & $\checkmark$ \\
Avg Dep Var & & $\checkmark$ \\
SD Dep Var & 12.595 & 12.595 \\
\hline \hline
\end{tabular}

Notes: This table presents the results from the main specification in equation $(5.1)$. The dependent variable is the total number of homicides excluding social leaders over total population. See Table 1 for more details on variables definition, predetermined controls, and standard errors. ${ }^{*}$ is significant at the $10 \%$ level, ${ }^{* *}$ is significant at the $5 \%$ level, $* * *$ is significant at the $1 \%$ level. 


\section{ONLINE APPENDIX}

\section{(Not for publication)}

\section{A.1. Data Appendix.}

A.1.1. Killing of social leaders: data sources and main patterns. Since 2006, Somos Defensores created an information system that records all the killings of social leaders, with the objective of producing permanent statistics about this type of violence in order to lobby national authorities and generate awareness on what they call a systematic (and intentional) practice.The registry is filled with the input of a large network of Human Rights organizations (over 500) with presence throughout the Colombian territory (especially in conflict-affected areas) and supplemented with fieldwork carried out by Somos Defensores to verify that assassinations of alleged leaders are indeed so. Efforts are made to avoid double counting.

For each murder case the dataset includes: the date and place of the event, the victim's name, the organization represented by the leader, and the presumed perpetrator. There are a total of 563 killings up to the first semester of $2018,91 \%$ of which remain unresolved by the judicial system. ${ }^{40}$ Most of the murdered leaders were part of local community councils $(33 \%)$, indigenous communities $(22 \%)$, or peasant organizations $(12 \%)-$ see Table A.1.1. For the purpose of our statistical analysis, we aggregate this information at the municipalitybi-annual level.

TABLE A.1.1. Leaders killed by activity

\begin{tabular}{lcc}
\hline \hline Activity & $\mathrm{N}$ & $\%$ \\
& $(1)$ & $(2)$ \\
\hline & & \\
Local council & 165 & 33.3 \\
Indigenous & 109 & 22.0 \\
Peasant & 59 & 11.9 \\
Conflict victims & 47 & 9.5 \\
Union member & 32 & 6.5 \\
Afro & 23 & 4.7 \\
Human rights & 19 & 3.8 \\
LGBT & 18 & 3.6 \\
Student-teacher & 20 & 4.0 \\
Women & 3 & 0.6 \\
\hline \hline
\end{tabular}

Notes: This table shows the distribution of homicides by type of social leader during our period of analysis, 2011:1 to 2017:2.

\footnotetext{
${ }^{40}$ See "La mayoría de asesinatos de líderes sociales quedan impunes: ONG Somos Defensores", El Espectador, 11/13/2018. Available from: https://www.elespectador.com/noticias/judicial/ la-mayoria-de-asesinatos-de-lideres-sociales-quedan-impunes-ong-somos-defensores-articulo-823451 (last accesses November 30, 2018).
} 
A.1.2. Construction of the measure of exposure to other armed groups. Following Acemoglu et al. (2015), our measure of exposure to other armed groups is obtained from the interaction of a presence dummy equivalent to that of FARC (and during the same period, 2011:1-2014:2), and a vector of (distance-penalized) neighboring municipalities. Specifically, we define the matrix $\mathbf{F}$ with entries $f_{i j}$ as:

$$
f_{i j}=\frac{1}{1+d_{i j}\left(1+e_{i j}\right)}
$$

where $d_{i j}$ is the euclidean distance between municipalities $i$ and $j$, and $e_{i j}$ is the difference in altitude between municipality $i$ and $j$ (used to compute the an "effective distance", corrected by terrain ruggedness). Let $N(i)$ be the set of neighbors that share a common border with municipality $i$ and constitutes the $i^{\text {th }}$ row of the matrix $\mathbf{N}$, which summarizes all the neighbors of every municipality and has entries:

$$
n_{i j}= \begin{cases}0 & \text { if } j \notin N(i) \\ f_{i j} & \text { if } j \in N(i)\end{cases}
$$

Note that the resulting measure varies between 0 an 2 and accounts for the differential exposure of other armed groups given the neighborhood of a specific municipality.

Using this definition we end up with a sample composed by 99 municipalities with FARC presence, 462 municipalities exposed to the influence of other armed groups, and 81 municipalities with presence of FARC and exposed to the influence of other armed groups.

\section{A.2. Additional Specifications.}

A.2.1. Testing for parallel trends. The "parallel trends" assumption can be partially assessed by estimating following dynamic version of (5.1):

$$
\begin{aligned}
y_{m d t}= & \alpha_{m}+\delta_{d t}+\sum_{j \in T} \text { FARC }_{m} \times \text { ExposureOthers }_{m} \times \delta_{j}^{1}+\sum_{j \in T} \text { FARC }_{m} \times \delta_{j}^{2} \\
& +\sum_{j \in T} \text { ExposureOthers } \\
m & \times \delta_{j}^{3}+\sum_{c \in \mathbf{X}_{\mathbf{m}}} \gamma^{\prime}\left(c \times \delta_{t}\right)+\epsilon_{m d t}
\end{aligned}
$$

where $T$ includes all semester of our sample period but the second semester of 2014, which is the period right before the ceasefire. The parameters $\delta_{j}^{1}$ can be interpreted as the differential killings in municipalities with FARC presence that are exposed to the influence of other armed groups in year-semester $j$, relative to the year-semester right before the ceasefire.

A.2.2. Testing potential mechanisms. We can use municipal-level variation across specific characteristics to estimate heterogenous effects that can shed some light regarding the underlying mechanisms of the main 


\section{Figure A.2.1.1. Dynamic estimation and parallel trends} Homicides of Social Leaders over Total Population

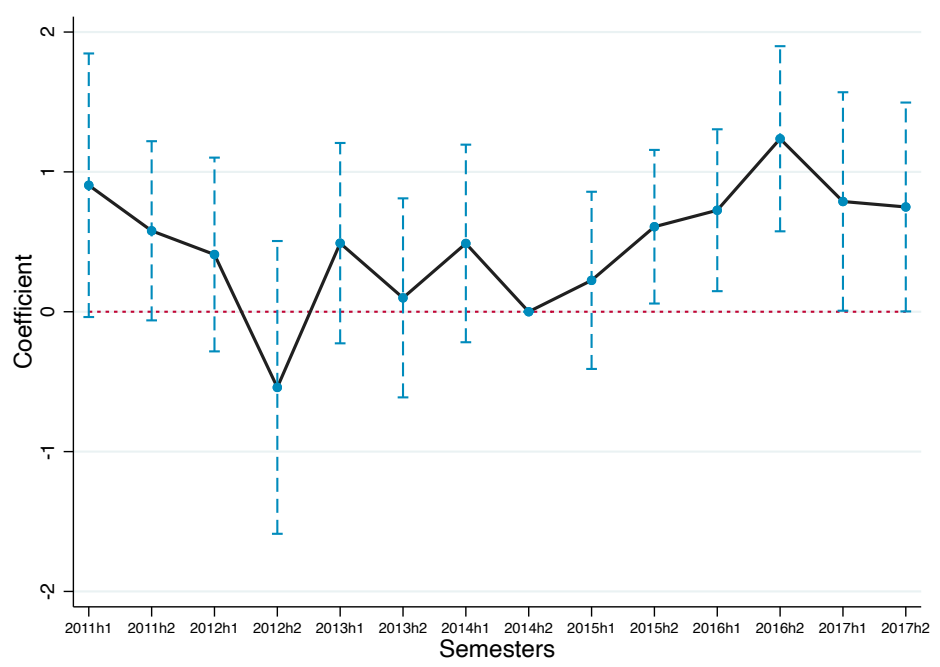

A. Without controls

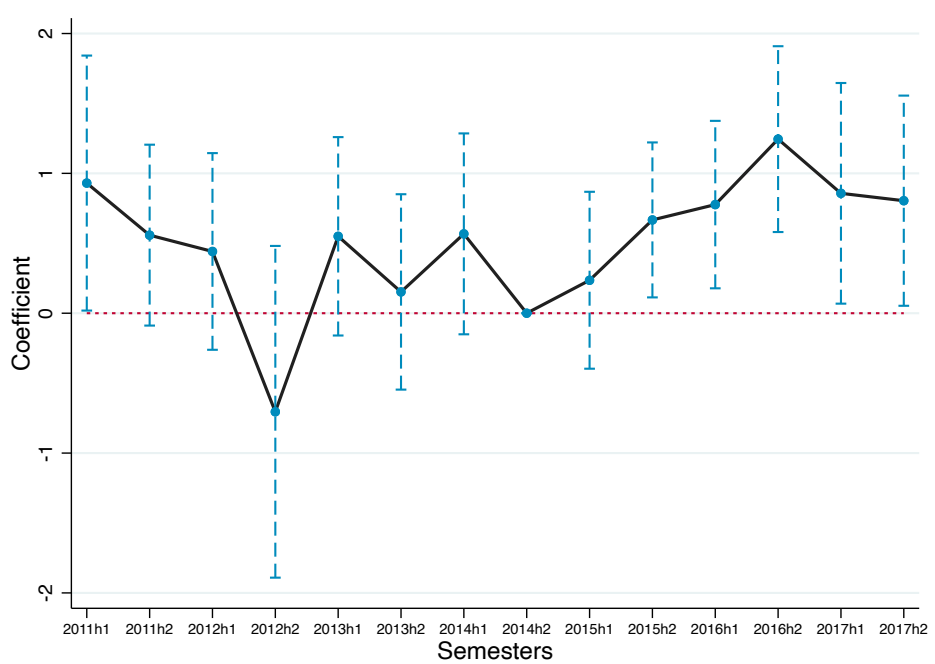

B. With controls

Notes: This figure presents the coefficients from our dynamic specification presented in equation (A.2.1.1). We present the point estimates of the regression and the confidence of interval at the $90 \%$.

effect of interest. In particular, the killing of leaders may be exacerbated in municipalities that are more economically attractive for the controlling armed group. Moreover, municipalities with better state capacity and a more effective judiciary are likely to attenuate the unintended violent incentive provided by the ceasefire in formerly FARC strongholds. We thus divide a set of potential mechanisms into these two categories (attractiveness and state capacity) and test whether the estimated average effects entail some 
variation across these dimensions.

To that end, we augment the main specification in equation (5.1) by adding a fourth interaction term. Specifically, let the municipality characteristic $Z_{m}$ (measured before the ceasefire) be a measure of the relative attractiveness or else the relative cost of disputing a FARC stronghold. We estimate:

$$
\begin{aligned}
y_{m d t} & =\alpha_{m}+\delta_{d t}+\beta_{1} \times \text { FARC }_{m} \times \text { ExposureOthers }_{m} \times Z_{m} \times \text { Cease }_{t} \\
& +\beta_{2} \times \text { ExposureOthers }_{m} \times Z_{m} \times \text { Cease }_{t}+\beta_{3} \times \text { FARC }_{m} \times Z_{m} \times \text { Cease }_{t} \\
& +\beta_{4} \times \text { FARC }_{m} \times \text { ExposureOthers }_{m} \times \text { Cease }_{t}+\beta_{5} \times \text { FARC }_{m} \times \text { Cease }_{t} \\
& +\beta_{6} \times \text { ExposureOthers }_{m} \times \text { Cease }_{t}+\beta_{7} \times Z_{m} \times \text { Cease }_{t}+\sum_{c \in \mathbf{X}_{\mathbf{m}}} \gamma^{\prime}\left(c \times \alpha_{t}\right)+\epsilon_{m d t}
\end{aligned}
$$

Our coefficient of interest, $\beta_{1}$, captures the differential killing of social leaders in places with FARC presence and exposed to other armed groups in municipalities with characteristic $Z_{m}$. Note that the results coming from this test are suggestive about potential mechanisms, but not necessarily causal. They have to be interpreted with caution.

Using the above specifications we estimate the impact of the December 2014 permanent ceasefire on the killing of social leaders in areas previously dominated by FARC and exposed to other armed groups (equation 5.1), the dynamic persistence of this effect (equation A.2.1.1), and heterogeneous effects given by the relative attractiveness of disputed municipalities as well as their institutional capacity (equation A.2.2.1). The next section reports the estimated results.

A.2.3. Ceasefire or implementation? The signature of the final peace agreement at the end of 2016 was followed by a mobilization of FARC fronts away from their areas of operation and into specific zones where, under the monitoring of a UN Peace Mission, FARC disarmed and started their reincorporation process. Thus, one could argue that, while the permanent ceasefire opened a window of opportunity for other armed groups to dispute the control of FARC-dominated territories, the mobilization of FARC personnel during the agreement implementation stage further facilitated the occupation of former FARC areas by other armed groups. If this is the case, then there should be a differential effect on the killing of social leaders starting in 2017:1, relative to that observed during the post ceasefire, pre-implementation period (2015:1 to 2016:2).

However, as mentioned in the introduction, the quest for territorial control by armed groups entails the selective killing of civilians to induce fear and encourage allegiance and support, and this strategy is independent of whether a ceasefire-compliant FARC is present or not. This, on the other hand, argues against any differential effect in the killing of social leaders after the implementation of the agreement relative to the ceasefire period. We take a skeptical view and estimate this potential differential effect across 
the post cease-fire period through the following model:

$$
\begin{aligned}
y_{m d t} & =\alpha_{m}+\delta_{d t}+\beta_{1} \times \text { FARC }_{m} \times \text { ExposureOthers }_{m} \times \text { Implementation }_{t} \\
& +\beta_{2} \times \text { FARC }_{m} \times \text { Implementation }_{t}+\beta_{3} \times \text { ExposureOthers }_{m} \times \text { Implementation }_{t} \\
& +\beta_{4} \times \text { FARC }_{m} \times \text { ExposureOthers }_{m} \times \text { Cease }_{t}+\beta_{5} \times \text { FARC }_{m} \times \text { Cease }_{t} \\
& +\beta_{6} \times \text { ExposureOthers }_{m} \times \text { Cease }_{t}+\sum_{c \in \mathbf{X}_{\mathbf{m}}} \gamma^{\prime}\left(c \times \delta_{t}\right)+\epsilon_{m d t}
\end{aligned}
$$

where Implementation $_{t}$ is a dummy that takes the value of one after beginning of the peace agreement implementation phase, in first semester of 2017. Relative to $\beta_{4}, \beta_{1}$ captures the differential change in the killing of social leaders during the implementation stage in comparison with the ceasefire period for the interaction of interest.

Table A.2.3.1 shows the estimated coefficients from specification. The coefficient of interest is not statistically significant which suggests no differential effect on the rate of leader killed in this sub-period. ${ }^{41}$ We interpret this as suggesting that the ceasefire, which was by and large respected by FARC (to credibly signal their willingness of reaching a peace agreement) was a high enough incentive for other armed groups to dispute the control of this group's territorial strongholds, and there was no differential such incentive when the implementation stage of the peace agreement started.

\section{A.3. Additional Figures and Tables.}

\footnotetext{
${ }^{41}$ The Table also shows that the level effect for this sub-period is positive and statistically significant when the pre-determined controls are added.
} 
TABLE A.2.3.1. Killing of social leaders during the cease fire and the implementation of the peace agreement

\begin{tabular}{|c|c|c|}
\hline & \multicolumn{2}{|c|}{ Killing rate } \\
\hline & $(1)$ & $(2)$ \\
\hline \multirow{2}{*}{ Implementation $\times$ FARC $\times$ ExposureOthers } & 0.070 & 0.100 \\
\hline & $(0.291)$ & $(0.294)$ \\
\hline \multirow[t]{2}{*}{ Cease $\times$ FARC $\times$ ExposureOthers } & $0.395^{* *}$ & $0.419^{* *}$ \\
\hline & $(0.190)$ & $(0.194)$ \\
\hline \multirow[t]{2}{*}{ Implementation $\times$ FARC } & -0.074 & -0.098 \\
\hline & $(0.211)$ & $(0.226)$ \\
\hline \multirow[t]{2}{*}{ Cease $\times$ FARC } & -0.112 & -0.099 \\
\hline & $(0.110)$ & $(0.113)$ \\
\hline \multirow[t]{2}{*}{ Implementation $\times$ ExposureOthers } & 0.027 & -0.016 \\
\hline & $(0.085)$ & $(0.095)$ \\
\hline \multirow[t]{2}{*}{ Cease $\times$ ExposureOthers } & $-0.264^{* * *}$ & $-0.273^{* * *}$ \\
\hline & $(0.101)$ & $(0.106)$ \\
\hline \multirow{2}{*}{ Implementation + Cease $\times$ FARC $\times$ ExposureOthers } & 0.465 & $0.519^{*}$ \\
\hline & $(0.290)$ & $(0.296)$ \\
\hline Observations & 14966 & 14966 \\
\hline Municipalities & 1069 & 1069 \\
\hline Municipality FE & $\checkmark$ & $\checkmark$ \\
\hline Department-Period FE & $\checkmark$ & $\checkmark$ \\
\hline Controls & & $\checkmark$ \\
\hline Avg Dep Var & 0.101 & 0.101 \\
\hline SD Dep Var & 1.083 & 1.083 \\
\hline
\end{tabular}

Notes: This table presents the results from the main specification in equation (A.2.3.1). The dependent variable is the number of homicides of social leaders over total population. Implementation is a dummy that takes the value one for the period after 2017:1. See Table 1 for more details on variables definition, predetermined controls, and standard errors. ${ }^{*}$ is significant at the $10 \%$ level, ${ }^{* *}$ is significant at the $5 \%$ level, $* * *$ is significant at the $1 \%$ level. 


\section{Figure A.3.1. Evolution of killings by leader type}

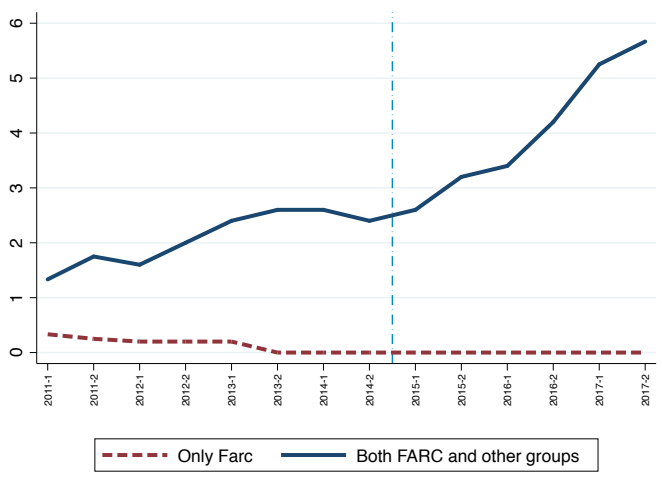

A. Community leaders

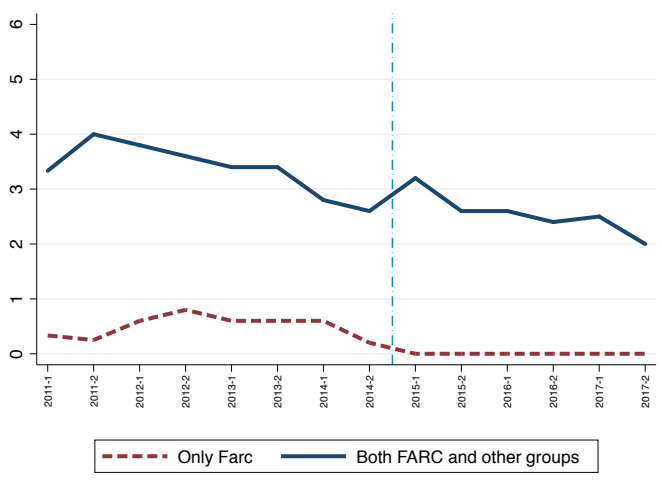

C. Afro-Indigenous

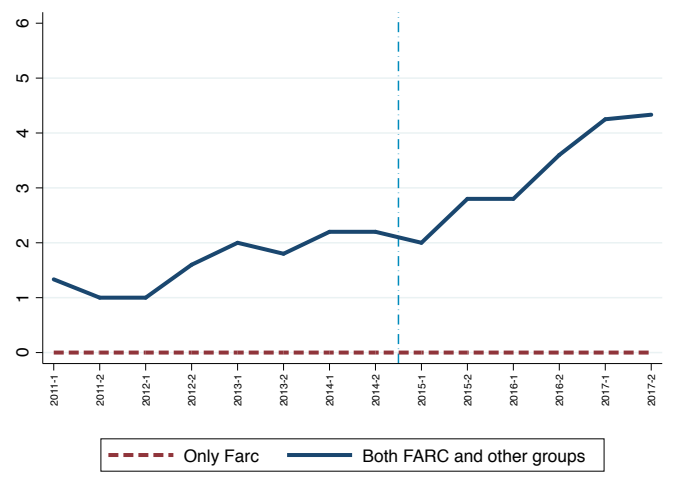

B. Conflict related organizations

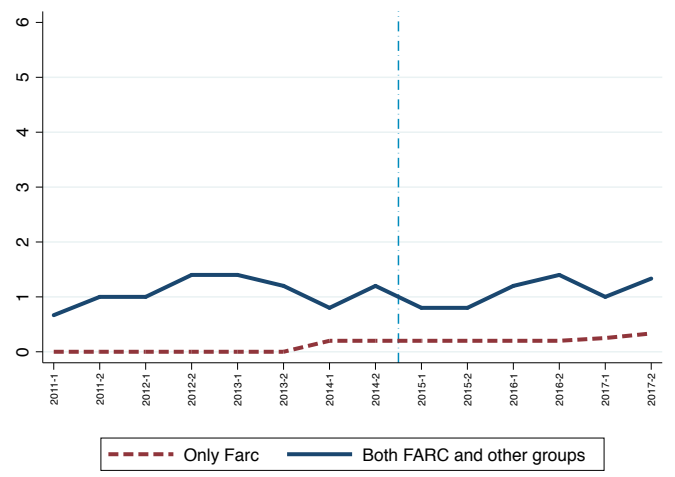

D. Others

Notes: This figure presents the evolution of killings of social leaders from 2010 to 2017 by type of leader. We split the sample by type of municipality into those with FARC and other groups exposure, and only FARC. We define those municipalities with exposure as those that have any positive exposure. Panel A presents the evolution for community leaders (30\%), panel B for leaders of peace related organizations (20\%), panel C for afro and indigenous leaders $(27 \%)$, while panel D present the rest $(23 \%)$. In all the panels we show one-year moving averages to smooth the data. 


\section{TABle A.3.1. Descriptive Statistics: Time-invariant variables}

\begin{tabular}{|c|c|c|c|c|}
\hline & Mean & Std. Dev. & Min & Max \\
\hline \multicolumn{5}{|l|}{ Social leaders killings } \\
\hline Dummy of any killing & 0.021 & 0.144 & 0.0 & 1.0 \\
\hline Number of killings & 0.026 & 0.189 & 0.0 & 5.0 \\
\hline Rate of killings & 0.113 & 1.051 & 0.0 & 38.4 \\
\hline \multicolumn{5}{|l|}{ Illegal groups presence } \\
\hline FARC & 0.093 & 0.290 & 0.0 & 1.0 \\
\hline Exposure to other armed groups & 0.128 & 0.325 & 0.0 & 1.3 \\
\hline Exposure to neo-paramilitary groups & 0.103 & 0.292 & 0.0 & 1.3 \\
\hline Exposure to ELN & 0.035 & 0.178 & 0.0 & 1.2 \\
\hline \multicolumn{5}{|l|}{ Geographic } \\
\hline Altitude (Km) & 1.149 & 0.903 & 0.0 & 3.1 \\
\hline Distance to main city $\mathrm{kms}$ & 80.772 & 55.551 & 0.0 & 376.1 \\
\hline Rural share & 0.579 & 0.229 & 0.0 & 1.0 \\
\hline Municipal area in $\mathrm{km}^{2}$ & 865.268 & 2996.145 & 15.0 & 65674.0 \\
\hline \multicolumn{5}{|l|}{ Basic socioeconomic } \\
\hline Log (population) & 9.489 & 0.948 & 6.9 & 12.2 \\
\hline Poverty index & 69.924 & 15.631 & 14.3 & 100.0 \\
\hline Literacy rate & 83.661 & 8.447 & 30.0 & 97.8 \\
\hline Language test scores & 47.977 & 2.200 & 38.4 & 57.1 \\
\hline Math test scores & 47.863 & 2.694 & 39.4 & 61.7 \\
\hline \multicolumn{5}{|l|}{ Fiscal } \\
\hline Log (Tax income) & 6.726 & 1.408 & 0.0 & 12.1 \\
\hline Good fiscal policy index & 66.239 & 9.359 & 0.0 & 94.2 \\
\hline
\end{tabular}

Notes: Control variables measure before 2010. Altitude above sea level of the urban center of each municipality. Distance is linear distance to the state's capital. Rural share is the percentage of population outside urban center. Municipal area official in $\mathrm{km}^{2}$. Total municipal population (in logs). Proportion of people in poverty according to multidimensional index. Percentage literate population. Math and language scores is the municipal average scores per area for high-school graduates in the official standardized test. Tax income is municipal total amount collected taxes. Good fiscal policy index of efficiency, legal requirements and management of the fiscal resources. 
TABLE A.3.2. Descriptive Statistics by illegal groups presence

\begin{tabular}{|c|c|c|c|}
\hline & $\begin{array}{c}\text { Presence } \\
\text { FARC } \\
(1) \\
\end{array}$ & $\begin{array}{c}\text { Presence } \\
\text { Other Groups } \\
(2) \\
\end{array}$ & $\begin{array}{c}\text { Only FARC vs. } \\
\text { Both FARC and } \\
\text { Other Groups } \\
(3)\end{array}$ \\
\hline \multicolumn{4}{|l|}{ Social leaders killings } \\
\hline Dummy of any killing & $\begin{array}{c}0.058 \\
{[0.000]}\end{array}$ & $\begin{array}{c}0.052 \\
{[0.000]}\end{array}$ & $\begin{array}{c}0.038 \\
{[0.024]}\end{array}$ \\
\hline Number of killings & $\begin{array}{c}0.073 \\
{[0.000]}\end{array}$ & $\begin{array}{c}0.061 \\
{[0.000]}\end{array}$ & $\begin{array}{c}0.049 \\
{[0.026]}\end{array}$ \\
\hline Rate of killings & $\begin{array}{c}0.290 \\
{[0.000]}\end{array}$ & $\begin{array}{c}0.243 \\
{[0.000]}\end{array}$ & $\begin{array}{c}0.209 \\
{[0.099]}\end{array}$ \\
\hline \multicolumn{4}{|l|}{ Geographic } \\
\hline Altitude $(\mathrm{Km})$ & $\begin{array}{l}-0.276 \\
{[0.001]}\end{array}$ & $\begin{array}{l}-0.542 \\
{[0.000]}\end{array}$ & $\begin{array}{l}-0.134 \\
{[0.436]}\end{array}$ \\
\hline Distance to main city kms & $\begin{array}{l}13.673 \\
{[0.023]}\end{array}$ & $\begin{array}{l}31.071 \\
{[0.000]}\end{array}$ & $\begin{array}{l}25.678 \\
{[0.057]}\end{array}$ \\
\hline Rural share & $\begin{array}{c}0.062 \\
{[0.006]}\end{array}$ & $\begin{array}{l}-0.099 \\
{[0.000]}\end{array}$ & $\begin{array}{l}-0.004 \\
{[0.944]}\end{array}$ \\
\hline Municipal area in $\mathrm{km}^{2}$ & $\begin{array}{c}1900.961 \\
{[0.000]}\end{array}$ & $\begin{array}{c}833.764 \\
{[0.001]}\end{array}$ & $\begin{array}{c}1140.908 \\
{[0.149]}\end{array}$ \\
\hline Basic socioeconomic & & & \\
\hline Log (population) & $\begin{array}{c}0.552 \\
{[0.000]}\end{array}$ & $\begin{array}{c}0.760 \\
{[0.000]}\end{array}$ & $\begin{array}{c}0.322 \\
{[0.099]}\end{array}$ \\
\hline Poverty index & $\begin{array}{c}9.026 \\
{[0.000]}\end{array}$ & $\begin{array}{c}5.026 \\
{[0.001]}\end{array}$ & $\begin{array}{c}7.552 \\
{[0.016]}\end{array}$ \\
\hline Literacy rate & $\begin{array}{l}-5.038 \\
{[0.000]}\end{array}$ & $\begin{array}{l}-3.873 \\
{[0.000]}\end{array}$ & $\begin{array}{l}-7.021 \\
{[0.000]}\end{array}$ \\
\hline Language test scores & $\begin{array}{l}-0.765 \\
{[0.001]}\end{array}$ & $\begin{array}{l}-0.888 \\
{[0.000]}\end{array}$ & $\begin{array}{l}-0.973 \\
{[0.014]}\end{array}$ \\
\hline Math test scores & $\begin{array}{l}-1.241 \\
{[0.000]}\end{array}$ & $\begin{array}{l}-0.774 \\
{[0.003]}\end{array}$ & $\begin{array}{l}-0.971 \\
{[0.061]}\end{array}$ \\
\hline Fiscal & & & \\
\hline Log (Tax income) & $\begin{array}{c}0.363 \\
{[0.002]}\end{array}$ & $\begin{array}{c}0.557 \\
{[0.001]}\end{array}$ & $\begin{array}{c}0.250 \\
{[0.346]}\end{array}$ \\
\hline Good fiscal policy index & $\begin{array}{c}0.184 \\
{[0.813]}\end{array}$ & $\begin{array}{c}0.263 \\
{[0.826]}\end{array}$ & $\begin{array}{l}-0.831 \\
{[0.560]}\end{array}$ \\
\hline
\end{tabular}

Notes: Control variables measured before 2010 and social leader killings before 2014:2. Column 1 reports the differences between municipalities with FARC presence and municipalities with no presence of any group. Column 2 reports differences between municipalities with presence of other armed groups and municipalities with no presence of any group. Column 3 reports differences between municipalities with presence of FARC only and municipalities with presence of both FARC and other armed groups. p-value in square brakets. 
TABLE A.3.3. Killing of social leaders, FARC presence and exposure to other armed groups: Using Negative Binomial and Conditional Poisson models

\begin{tabular}{|c|c|c|c|c|}
\hline & \multicolumn{2}{|c|}{ Negative Binomial } & \multicolumn{2}{|c|}{ Conditional Poisson } \\
\hline & (1) & (2) & (3) & (4) \\
\hline Cease $\times$ FARC $\times$ ExposureOthers & $\begin{array}{c}1.503^{* * *} \\
(0.478)\end{array}$ & $\begin{array}{c}1.428^{* * *} \\
(0.521)\end{array}$ & $\begin{array}{c}2.013^{* * *} \\
(0.279)\end{array}$ & $\begin{array}{c}2.310^{* * *} \\
(0.309)\end{array}$ \\
\hline Cease $\times$ FARC & $\begin{array}{c}0.020 \\
(0.313)\end{array}$ & $\begin{array}{l}-0.222 \\
(0.347)\end{array}$ & $\begin{array}{c}-0.807^{* * *} \\
(0.155)\end{array}$ & $\begin{array}{l}-1.185^{* * *} \\
(0.190)\end{array}$ \\
\hline Cease $\times$ ExposureOthers & $\begin{array}{c}-0.721^{* *} \\
(0.332)\end{array}$ & $\begin{array}{c}-0.805^{* *} \\
(0.372)\end{array}$ & $\begin{array}{c}-1.320^{* * *} \\
(0.199)\end{array}$ & $\begin{array}{l}-1.295^{* * *} \\
(0.212)\end{array}$ \\
\hline Observations & 2786 & 2786 & 2786 & 2786 \\
\hline Municipalities & 199 & 199 & 199 & 199 \\
\hline Municipality FE & $\checkmark$ & $\checkmark$ & $\checkmark$ & $\checkmark$ \\
\hline Period FE & $\checkmark$ & $\checkmark$ & $\checkmark$ & $\checkmark$ \\
\hline Controls & & $\checkmark$ & & $\checkmark$ \\
\hline Avg Dep Var & 0.101 & 0.101 & 0.101 & 0.101 \\
\hline SD Dep Var & 1.083 & 1.083 & 1.083 & 1.083 \\
\hline
\end{tabular}

Notes: This table presents the results from the main specification in equation (5.1). We exploit municipallevel variation by semester, over the period 2011:1 to 2017:2. All the columns use as dependent variable the total number of homicides of social leaders. Columns (1) and (2) estimate a negative binomial model while columns (3) and (4) estimate a conditional poisson model. Cease is a dummy that takes the value one for the period after 2015:1. FARC is a dummy for those municipalities with FARC presence. ExposureOthers is a continuous variable that measures ELN or paramilitary groups presence in the municipality or their (distance-penalized) vicinity. Predetermined municipal controls includes logarithm of the population in 2010, municipality area, average elevation, distance to the closest major city, share of population under poverty, literacy rate, math and language test scores, index of rurality, log of tax income and index of good fiscal policy. Standard errors in parentheses. ${ }^{*}$ is significant at the $10 \%$ level, $* *$ is significant at the $5 \%$ level, ${ }^{* * *}$ is significant at the $1 \%$ level. 
TABLE A.3.4. Killing of social leaders, FARC presence, and exposure to other armed groups

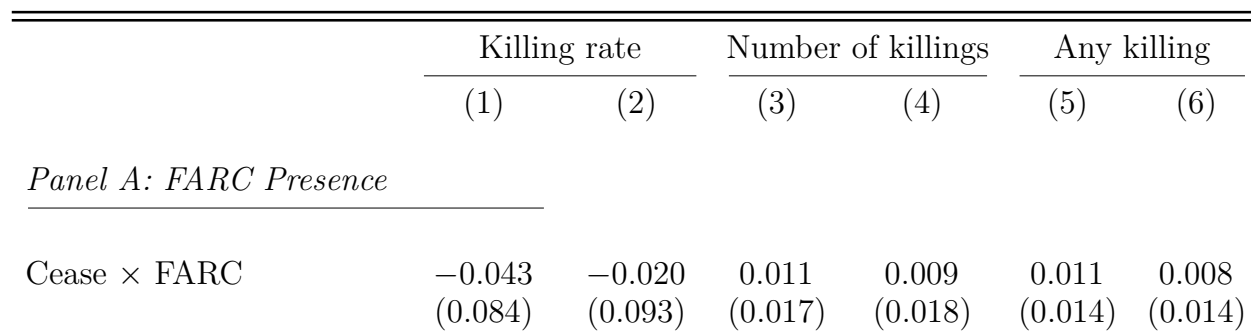

Panel B: Other Groups Presence

\begin{tabular}{lcccccc} 
Cease $\times$ Exposure Others & $-0.156^{* *}$ & $-0.170^{* *}$ & -0.009 & -0.013 & -0.008 & -0.013 \\
& $(0.076)$ & $(0.080)$ & $(0.015)$ & $(0.016)$ & $(0.011)$ & $(0.012)$ \\
& & & & & & \\
Observations & 14966 & 14966 & 14966 & 14966 & 14966 & 14966 \\
Municipalities & 1069 & 1069 & 1069 & 1069 & 1069 & 1069 \\
Municipality FE & $\checkmark$ & $\checkmark$ & $\checkmark$ & $\checkmark$ & $\checkmark$ & $\checkmark$ \\
Department-Period FE & $\checkmark$ & $\checkmark$ & $\checkmark$ & $\checkmark$ & $\checkmark$ & $\checkmark$ \\
Controls & & $\checkmark$ & & $\checkmark$ & & $\checkmark$ \\
Avg Dep Var & 0.101 & 0.101 & 0.028 & 0.028 & 0.021 & 0.021 \\
SD Dep Var & 1.083 & 1.083 & 0.219 & 0.219 & 0.144 & 0.144 \\
\hline
\end{tabular}

Notes: This table presents the results from the main specification in equation (5.1). We exploit municipallevel variation by semester, over the period 2011:1 to 2017:2. Columns (1) and (2) use the number of homicides of social leaders over total population, columns (3) and (4) use as dependent variable the total number of homicides of social leaders, while columns (5) and (6) use a dummy that takes the value one if there was at least one social leader assassinated. Cease is a dummy that takes the value one for the period after 2015:1. FARC is a dummy for those municipalities with FARC presence. ExposureOthers is a continuous variable that measures ELN or paramilitary groups presence in the municipality or their (distance-penalized) vicinity. Predetermined municipal controls includes logarithm of the population in 2010, municipality area, average elevation, distance to the closest major city, share of population under poverty, literacy rate, math and language test scores, index of rurality, log of tax income and index of good fiscal policy. Errors in parentheses control for spatial and first-order time correlation (see Conley, 1999, Conley, 2016). We allow spatial correlation to extend to up to $279 \mathrm{~km}$ from each municipality's centroid to ensure that each municipality has at least one neighbor. * is significant at the $10 \%$ level, ** is significant at the $5 \%$ level, $* * *$ is significant at the $1 \%$ level. 
TABLE A.3.5. Killing of social leaders, FARC presence, and exposure to other armed groups before the ceasefire

\begin{tabular}{|c|c|c|c|c|c|c|}
\hline & \multicolumn{2}{|c|}{ Killing rate } & \multicolumn{2}{|c|}{ Number of killings } & \multicolumn{2}{|c|}{ Any killing } \\
\hline & (1) & (2) & (3) & (4) & (5) & (6) \\
\hline Trend $\times$ FARC $\times$ ExposureOthers & $\begin{array}{l}-0.080 \\
(0.055)\end{array}$ & $\begin{array}{l}-0.072 \\
(0.055)\end{array}$ & $\begin{array}{c}0.003 \\
(0.011)\end{array}$ & $\begin{array}{c}0.003 \\
(0.011)\end{array}$ & $\begin{array}{c}0.003 \\
(0.008)\end{array}$ & $\begin{array}{c}0.003 \\
(0.008)\end{array}$ \\
\hline Trend $\times$ FARC & $\begin{array}{c}0.026 \\
(0.029)\end{array}$ & $\begin{array}{c}0.034 \\
(0.031)\end{array}$ & $\begin{array}{c}0.001 \\
(0.005)\end{array}$ & $\begin{array}{c}0.002 \\
(0.005)\end{array}$ & $\begin{array}{l}-0.002 \\
(0.003)\end{array}$ & $\begin{array}{l}-0.002 \\
(0.004)\end{array}$ \\
\hline Trend $\times$ ExposureOthers & $\begin{array}{l}0.018 \\
(0.024)\end{array}$ & $\begin{array}{c}0.024 \\
(0.027)\end{array}$ & $\begin{array}{c}0.004 \\
(0.004)\end{array}$ & $\begin{array}{l}0.005 \\
(0.004)\end{array}$ & $\begin{array}{c}0.002 \\
(0.003)\end{array}$ & $\begin{array}{c}0.002 \\
(0.003)\end{array}$ \\
\hline Observations & 8552 & 8552 & 8552 & 8552 & 8552 & 8552 \\
\hline Municipalities & 1069 & 1069 & 1069 & 1069 & 1069 & 1069 \\
\hline Municipality FE & $\checkmark$ & $\checkmark$ & $\checkmark$ & $\checkmark$ & $\checkmark$ & $\checkmark$ \\
\hline Department-Period FE & $\checkmark$ & $\checkmark$ & $\checkmark$ & $\checkmark$ & $\checkmark$ & $\checkmark$ \\
\hline Controls & & $\checkmark$ & & $\checkmark$ & & $\checkmark$ \\
\hline Avg Dep Var & 0.101 & 0.101 & 0.028 & 0.028 & 0.021 & 0.021 \\
\hline SD Dep Var & 1.083 & 1.083 & 0.219 & 0.219 & 0.144 & 0.144 \\
\hline
\end{tabular}

Notes: This table presents the results from specification that includes linear trends interacted with three different treatments before the ceasefire. We exploit municipal-level variation by semester, over the period 2011:1 to 2014:2. Columns (1) and (2) use the number of homicides of social leaders over total population, columns (3) and (4) use as dependent variable the total number of homicides of social leaders, while columns (5) and (6) use a dummy that takes the value one if there was at least one social leader assassinated. Trend is a trend variable, FARC is a dummy for those municipalities with FARC presence. ExposureOthers is a continuous variable that measures ELN or paramilitary groups presence in the municipality or their (distance-penalized) vicinity. Predetermined municipal controls includes logarithm of the population in 2010, municipality area, average elevation, distance to the closest major city, share of population under poverty, literacy rate, math and language test scores, index of rurality, log of tax income and index of good fiscal policy. Errors in parentheses control for spatial and first-order time correlation (see Conley, 1999, Conley, 2016). We allow spatial correlation to extend to up to $279 \mathrm{~km}$ from each municipality's centroid to ensure that each municipality has at least one neighbor. ${ }^{*}$ is significant at the $10 \%$ level, ${ }^{* *}$ is significant at the $5 \%$ level, ${ }^{* * *}$ is significant at the $1 \%$ level. 
TABLE A.3.6. Killing of social leaders, FARC presence, and exposure to other armed groups: Placebo Land Agreement in 2013

\begin{tabular}{|c|c|c|c|c|c|c|}
\hline & \multicolumn{2}{|c|}{ Killing rate } & \multicolumn{2}{|c|}{ Number of killings } & \multicolumn{2}{|c|}{ Any killing } \\
\hline & (1) & (2) & (3) & $(4)$ & $(5)$ & (6) \\
\hline Placebo $\times$ FARC $\times$ ExposureOthers & $\begin{array}{l}-0.068 \\
(0.267)\end{array}$ & $\begin{array}{c}0.011 \\
(0.284)\end{array}$ & $\begin{array}{c}0.038 \\
(0.048)\end{array}$ & $\begin{array}{c}0.042 \\
(0.049)\end{array}$ & $\begin{array}{c}0.015 \\
(0.039)\end{array}$ & $\begin{array}{c}0.017 \\
(0.039)\end{array}$ \\
\hline Placebo $\times$ FARC & $\begin{array}{c}0.035 \\
(0.141)\end{array}$ & $\begin{array}{c}0.057 \\
(0.150)\end{array}$ & $\begin{array}{l}-0.011 \\
(0.023)\end{array}$ & $\begin{array}{l}-0.011 \\
(0.025)\end{array}$ & $\begin{array}{l}-0.011 \\
(0.018)\end{array}$ & $\begin{array}{l}-0.013 \\
(0.018)\end{array}$ \\
\hline Placebo $\times$ ExposureOthers & $\begin{array}{l}-0.051 \\
(0.173)\end{array}$ & $\begin{array}{l}-0.038 \\
(0.180)\end{array}$ & $\begin{array}{c}0.013 \\
(0.019)\end{array}$ & $\begin{array}{c}0.017 \\
(0.019)\end{array}$ & $\begin{array}{c}0.007 \\
(0.015)\end{array}$ & $\begin{array}{c}0.006 \\
(0.014)\end{array}$ \\
\hline Observations & 8552 & 8552 & 8552 & 8552 & 8552 & 8552 \\
\hline Municipalities & 1069 & 1069 & 1069 & 1069 & 1069 & 1069 \\
\hline Municipality FE & $\checkmark$ & $\checkmark$ & $\checkmark$ & $\checkmark$ & $\checkmark$ & $\checkmark$ \\
\hline Department-Period FE & $\checkmark$ & $\checkmark$ & $\checkmark$ & $\checkmark$ & $\checkmark$ & $\checkmark$ \\
\hline Controls & & $\checkmark$ & & $\checkmark$ & & $\checkmark$ \\
\hline Avg Dep Var & 0.101 & 0.101 & 0.028 & 0.028 & 0.021 & 0.021 \\
\hline SD Dep Var & 1.083 & 1.083 & 0.219 & 0.219 & 0.144 & 0.144 \\
\hline
\end{tabular}

Notes: This table presents the results from the main specification in equation (5.1). We exploit municipallevel variation by semester, over the period 2011:1 to 2014:2. Columns (1) and (2) use the number of homicides of social leaders over total population, columns (3) and (4) use as dependent variable the total number of homicides of social leaders, while columns (5) and (6) use a dummy that takes the value one if there was at least one social leader assassinated. Placebo is a dummy that takes the value one for the period after 2013:1. FARC is a dummy for those municipalities with FARC presence. ExposureOthers is a continuous variable that measures ELN or paramilitary groups presence in the municipality or their (distance-penalized) vicinity. Predetermined municipal controls includes logarithm of the population in 2010, municipality area, average elevation, distance to the closest major city, share of population under poverty, literacy rate, math and language test scores, index of rurality, log of tax income and index of good fiscal policy. Errors in parentheses control for spatial and first-order time correlation (see Conley, 1999, Conley, 2016). We allow spatial correlation to extend to up to $279 \mathrm{~km}$ from each municipality's centroid to ensure that each municipality has at least one neighbor. ${ }^{*}$ is significant at the $10 \%$ level, $* *$ is significant at the $5 \%$ level, $* * *$ is significant at the $1 \%$ level. 
TABLE A.3.7. Measuring exposure to other armed groups using the presence in neighboring municipalities

\begin{tabular}{|c|c|c|c|c|c|c|}
\hline & \multicolumn{2}{|c|}{ Killing rate } & \multicolumn{2}{|c|}{ Number of killings } & \multicolumn{2}{|c|}{ Any killing } \\
\hline & (1) & (2) & (3) & (4) & (5) & (6) \\
\hline $\begin{array}{l}\text { Cease } \times \text { FARC } \times \text { ExposureOthers } \\
\text { ex }\end{array}$ & $\begin{array}{l}0.422^{* *} \\
(0.178)\end{array}$ & $\begin{array}{l}0.459^{* *} \\
(0.182)\end{array}$ & $\begin{array}{l}0.104^{* *} \\
(0.043)\end{array}$ & $\begin{array}{l}0.109^{* *} \\
(0.043)\end{array}$ & $\begin{array}{l}0.064^{*} \\
(0.035)\end{array}$ & $\begin{array}{l}0.068^{* *} \\
(0.034)\end{array}$ \\
\hline Cease $\times$ FARC & $\begin{array}{r}-0.245^{*} \\
(0.133)\end{array}$ & $\begin{array}{r}-0.249^{*} \\
(0.139)\end{array}$ & $\begin{array}{r}-0.046^{*} \\
(0.024)\end{array}$ & $\begin{array}{c}-0.050^{* *} \\
(0.025)\end{array}$ & $\begin{array}{l}-0.023 \\
(0.021)\end{array}$ & $\begin{array}{l}-0.027 \\
(0.022)\end{array}$ \\
\hline Cease $\times$ ExposureOthers & $\begin{array}{c}-0.243^{* * *} \\
(0.091)\end{array}$ & $\begin{array}{c}-0.279^{* * *} \\
(0.097)\end{array}$ & $\begin{array}{c}-0.035^{* * *} \\
(0.013)\end{array}$ & $\begin{array}{c}-0.041^{* * *} \\
(0.014)\end{array}$ & $\begin{array}{c}-0.025^{* *} \\
(0.010)\end{array}$ & $\begin{array}{c}-0.032^{* * *} \\
(0.011)\end{array}$ \\
\hline Observations & 14966 & 14966 & 14966 & 14966 & 14966 & 14966 \\
\hline Municipalities & 1069 & 1069 & 1069 & 1069 & 1069 & 1069 \\
\hline Municipality FE & $\checkmark$ & $\checkmark$ & $\checkmark$ & $\checkmark$ & $\checkmark$ & $\checkmark$ \\
\hline Period FE & $\checkmark$ & $\checkmark$ & $\checkmark$ & $\checkmark$ & $\checkmark$ & $\checkmark$ \\
\hline Controls & & $\checkmark$ & & $\checkmark$ & & $\checkmark$ \\
\hline Avg Dep Var & 0.101 & 0.101 & 0.028 & 0.028 & 0.021 & 0.021 \\
\hline SD Dep Var & 1.083 & 1.083 & 0.219 & 0.219 & 0.144 & 0.144 \\
\hline
\end{tabular}

Notes: This table presents the results from the main specification in equation (5.1). We exploit municipallevel variation by semester, over the period 2011:1 to 2017:2. Columns (1) and (2) use the number of homicides of social leaders over total population, columns (3) and (4) use as dependent variable the total number of homicides of social leaders, while columns (5) and (6) use a dummy that takes the value one if there was at least one social leader assassinated. Cease is a dummy that takes the value one for the period after 2015:1. FARC is a dummy for those municipalities with FARC presence. NeighOthers is the share of ELN or paramilitary groups presence among the municipality and their neighbors. Predetermined municipal controls includes logarithm of the population in 2010, municipality area, average elevation, distance to the closest major city, share of population under poverty, literacy rate, math and language test scores, index of rurality, log of tax income and index of good fiscal policy. Errors in parentheses control for spatial and first-order time correlation (see Conley, 1999, Conley, 2016). We allow spatial correlation to extend to up to $279 \mathrm{~km}$ from each municipality's centroid to ensure that each municipality has at least one neighbor. $*$ is significant at the $10 \%$ level, ${ }^{* *}$ is significant at the $5 \%$ level, $* * *$ is significant at the $1 \%$ level. 
TABLE A.3.8. Measuring exposure to other armed groups using all municipalities penalized by distance

\begin{tabular}{|c|c|c|c|c|c|c|}
\hline & \multicolumn{2}{|c|}{ Killing rate } & \multicolumn{2}{|c|}{ Number of killings } & \multicolumn{2}{|c|}{ Any killing } \\
\hline & (1) & $(2)$ & (3) & (4) & $(5)$ & (6) \\
\hline Cease $\times$ FARC $\times$ ExposureOthers & $\begin{array}{l}0.325^{* *} \\
(0.138)\end{array}$ & $\begin{array}{l}0.368^{* *} \\
(0.145)\end{array}$ & $\begin{array}{l}0.072^{* *} \\
(0.032)\end{array}$ & $\begin{array}{l}0.078^{* *} \\
(0.032)\end{array}$ & $\begin{array}{l}0.046^{*} \\
(0.027)\end{array}$ & $\begin{array}{l}0.050^{*} \\
(0.027)\end{array}$ \\
\hline Cease $\times$ FARC & $\begin{array}{l}-0.164 \\
(0.119)\end{array}$ & $\begin{array}{l}-0.177 \\
(0.124)\end{array}$ & $\begin{array}{l}-0.024 \\
(0.020)\end{array}$ & $\begin{array}{l}-0.030 \\
(0.020)\end{array}$ & $\begin{array}{l}-0.011 \\
(0.018)\end{array}$ & $\begin{array}{l}-0.016 \\
(0.019)\end{array}$ \\
\hline Cease $\times$ ExposureOthers & $\begin{array}{c}-0.219^{* * *} \\
(0.079)\end{array}$ & $\begin{array}{c}-0.239^{* * *} \\
(0.081)\end{array}$ & $\begin{array}{c}-0.027^{* * *} \\
(0.011)\end{array}$ & $\begin{array}{c}-0.031^{* * *} \\
(0.011)\end{array}$ & $\begin{array}{c}-0.019^{* *} \\
(0.008)\end{array}$ & $\begin{array}{c}-0.024^{* * *} \\
(0.009)\end{array}$ \\
\hline Observations & 14966 & 14966 & 14966 & 14966 & 14966 & 14966 \\
\hline Municipalities & 1069 & 1069 & 1069 & 1069 & 1069 & 1069 \\
\hline Municipality FE & $\checkmark$ & $\checkmark$ & $\checkmark$ & $\checkmark$ & $\checkmark$ & $\checkmark$ \\
\hline Period FE & $\checkmark$ & $\checkmark$ & $\checkmark$ & $\checkmark$ & $\checkmark$ & $\checkmark$ \\
\hline Controls & & $\checkmark$ & & $\checkmark$ & & $\checkmark$ \\
\hline Avg Dep Var & 0.101 & 0.101 & 0.028 & 0.028 & 0.021 & 0.021 \\
\hline SD Dep Var & 1.083 & 1.083 & 0.219 & 0.219 & 0.144 & 0.144 \\
\hline
\end{tabular}

Notes: This table presents the results from the main specification in equation (5.1). We exploit municipal-level variation by semester, over the period 2011:1 to 2017:2. Columns (1) and (2) use the number of homicides of social leaders over total population, columns (3) and (4) use as dependent variable the total number of homicides of social leaders, while columns (5) and (6) use a dummy that takes the value one if there was at least one social leader assassinated. Cease is a dummy that takes the value one for the period after 2015:1. FARC is a dummy for those municipalities with FARC presence. ExposureOthers is a continuous variable that measures ELN or paramilitary groups presence in the municipality and (distance-penalized) Colombian whole municipalities. Predetermined municipal controls includes logarithm of the population in 2010, municipality area, average elevation, distance to the closest major city, share of population under poverty, literacy rate, math and language test scores, index of rurality, log of tax income and index of good fiscal policy. Errors in parentheses control for spatial and first-order time correlation (see Conley, 1999, Conley, 2016). We allow spatial correlation to extend to up to $279 \mathrm{~km}$ from each municipality's centroid to ensure that each municipality has at least one neighbor. $*$ is significant at the $10 \%$ level, ${ }^{* *}$ is significant at the $5 \%$ level, *** is significant at the $1 \%$ level. 


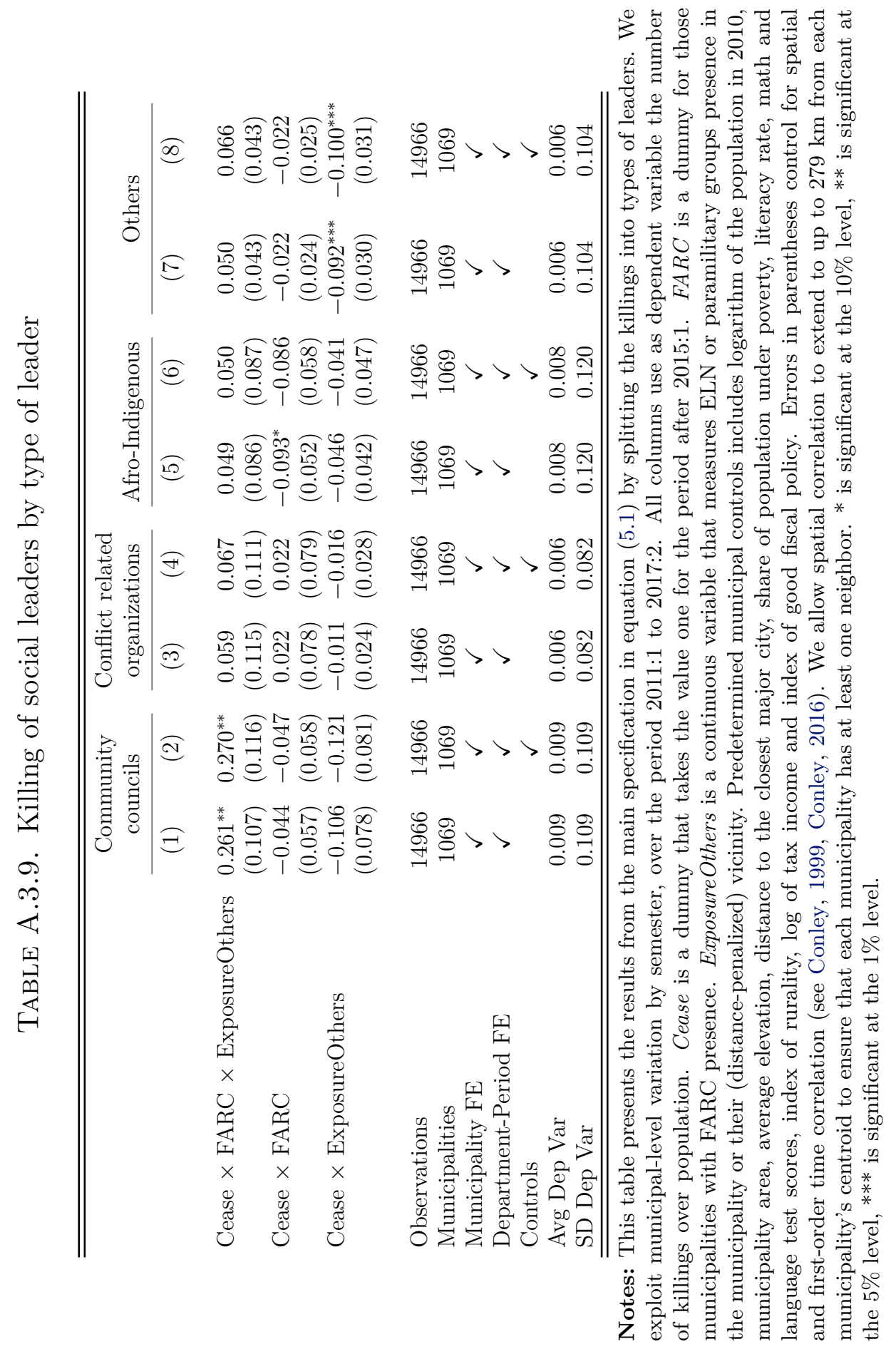


TABlE A.3.10. Killing of social leaders by exposure to different armed groups

\begin{tabular}{lcc}
\hline \hline & \multicolumn{2}{c}{ Killing Rate } \\
\cline { 2 - 3 } & $(1)$ & $(2)$ \\
Cease $\times$ FARC $\times$ Neo-Paramilitary & $0.340^{*}$ & $0.374^{*}$ \\
& $(0.205)$ & $(0.205)$ \\
Cease $\times$ FARC $\times$ ELN & $0.351^{*}$ & $0.395^{* *}$ \\
Cease $\times$ Neo-Paramilitary & $(0.196)$ & $(0.196)$ \\
& $-0.235^{* *}$ & $-0.256^{* *}$ \\
Cease $\times$ ELN & $(0.114)$ & $(0.118)$ \\
& $-0.211^{* *}$ & $-0.234^{* *}$ \\
Cease $\times$ FARC & $(0.099)$ & $(0.097)$ \\
& -0.123 & -0.120 \\
Observations & $(0.105)$ & $(0.110)$ \\
Municipalities & & \\
Municipality FE & 14966 & 14966 \\
Department-Period FE & 1069 & 1069 \\
Controls & $\checkmark$ & $\checkmark$ \\
Avg Dep Var & $\checkmark$ & $\checkmark$ \\
SD Dep Var & & $\checkmark$ \\
\hline \hline
\end{tabular}

Notes: This table presents the results from the main specification in equation (5.1). We exploit municipallevel variation by semester, over the period 2011:1 to 2017:2. The dependent variable is the number of homicides of social leaders over total population. Cease is a dummy that takes the value one for the period after 2015:1. FARC is a dummy for those municipalities with FARC presence. Neo-Paramilitary is a continuous variable that measures paramilitary groups presence and $E L N$ is a continuous variable that measures ELN presence, both measures in the municipality or their (distance-penalized) vicinity. Predetermined municipal controls includes logarithm of the population in 2010, municipality area, average elevation, distance to the closest major city, share of population under poverty, literacy rate, math and language test scores, index of rurality, log of tax income and index of good fiscal policy. Errors in parentheses control for spatial and first-order time correlation (see Conley, 1999, Conley, 2016). We allow spatial correlation to extend to up to $279 \mathrm{~km}$ from each municipality's centroid to ensure that each municipality has at least one neighbor. * is significant at the $10 \%$ level, $* *$ is significant at the $5 \%$ level, $* * *$ is significant at the $1 \%$ level. 
TABle A.3.11. Municipality characteristics before the ceasefire by FARC presence

\begin{tabular}{|c|c|c|}
\hline & $\begin{array}{c}(1) \\
\text { Avg without } \\
\text { FARC }\end{array}$ & $\begin{array}{c}(2) \\
\text { FARC } \\
\text { presence }\end{array}$ \\
\hline Land restitution & $\begin{array}{c}0.403 \\
(0.033)\end{array}$ & $\begin{array}{c}0.223^{* * *} \\
(0.071)\end{array}$ \\
\hline Judicial inefficiency & $\begin{array}{c}0.068 \\
(0.003)\end{array}$ & $\begin{array}{l}0.020^{*} \\
(0.011)\end{array}$ \\
\hline Electoral Risk & $\begin{array}{c}0.141 \\
(0.013)\end{array}$ & $\begin{array}{c}0.010 \\
(0.049)\end{array}$ \\
\hline Municipal income & $\begin{array}{l}85.861 \\
(3.844)\end{array}$ & $\begin{array}{c}-16.211^{* * *} \\
(5.920)\end{array}$ \\
\hline Municipal expenditure & $\begin{array}{l}101.917 \\
(4.788)\end{array}$ & $\begin{array}{c}-23.189^{* * *} \\
(7.586)\end{array}$ \\
\hline Total transfers & $\begin{array}{c}9.622 \\
(0.588)\end{array}$ & $\begin{array}{c}-3.409^{* * *} \\
(0.804)\end{array}$ \\
\hline Transfers from central government & $\begin{array}{l}46.070 \\
(1.551)\end{array}$ & $\begin{array}{l}-3.245 \\
(3.464)\end{array}$ \\
\hline National transfers & $\begin{array}{c}8.839 \\
(0.517)\end{array}$ & $\begin{array}{c}-3.096^{* * *} \\
(0.708)\end{array}$ \\
\hline Municipalities & \multicolumn{2}{|c|}{1063} \\
\hline
\end{tabular}

Notes: This table presents univariate regressions based on municipality characteristics before the ceasefire. Column 1 presents the average of each variable before the ceasefire (during 2011) for municipalities wihtout FARC presence. Column 2 presents the estimated coefficient and the standard errors from univariate regressions for FARC presnece. Land restitution is a dummy for those municipalities with the number of request for land restitution over the size of the municipality being above the median. Judicial inefficiency is the share of justice employees under disciplinary investigations. Electoral Risk is a dummy that takes the value of one if the municipality had abnormal behaviour during the previous three congressional elections. Municipal income is the sum of current income and capital income measured in thousands of current pesos per inhabitant. Municipal expenditure is the sum of current expenses and capital expenses measured in thousands of current pesos per inhabitant. Total transfers is the sum of the resources transferred to the municipality by another level of government measured in thousands of current pesos per inhabitant. Transfers from central goverment is transfers corresponds to resources from national entities transferred to the territorial entity measured in thousands of current pesos per inhabitant. National transfers is transfers from the Central Govern- ment by General Participation System (SGP) measured in thousands of current pesos per inhabitant. 
TABLE A.3.12. Differential effect on municipal finance by FARC presence after cease

\begin{tabular}{|c|c|c|c|c|c|}
\hline & $\begin{array}{l}\text { Municipal } \\
\text { Income }\end{array}$ & $\begin{array}{c}\text { Municipal } \\
\text { Expenditure }\end{array}$ & $\begin{array}{c}\text { Total } \\
\text { Transfers }\end{array}$ & $\begin{array}{c}\text { Transfers from } \\
\text { central goverment }\end{array}$ & $\begin{array}{l}\text { National } \\
\text { Transfers }\end{array}$ \\
\hline & (1) & $(2)$ & $(3)$ & (4) & $(5)$ \\
\hline Cease $\times$ FARC & $\begin{array}{c}29.152 \\
(29.176)\end{array}$ & $\begin{array}{c}37.872 \\
(36.776)\end{array}$ & $\begin{array}{l}-2.140 \\
(2.985)\end{array}$ & $\begin{array}{l}10.880 \\
(9.329)\end{array}$ & $\begin{array}{l}-0.318 \\
(2.310)\end{array}$ \\
\hline Observations & 7468 & 7468 & 7468 & 7483 & 7468 \\
\hline Municipalities & 1069 & 1069 & 1069 & 1069 & 1069 \\
\hline Municipality FE & $\checkmark$ & $\checkmark$ & $\checkmark$ & $\checkmark$ & $\checkmark$ \\
\hline Period FE & $\checkmark$ & $\checkmark$ & $\checkmark$ & $\checkmark$ & $\checkmark$ \\
\hline Controls & $\checkmark$ & $\checkmark$ & $\checkmark$ & $\checkmark$ & $\checkmark$ \\
\hline Avg Dep Var & 1114.769 & 1134.640 & 107.486 & 497.139 & 97.047 \\
\hline SD Dep Var & 911.294 & 919.664 & 118.829 & 304.267 & 107.631 \\
\hline
\end{tabular}

Notes: This table presents the results from the main specification in difference. We exploit municipal-level variation by year, over the period 2011 to 2017 . The dependent variable is the measure per capita. Cease is a dummy that takes the value one for the period after 2015, FARC is a dummy for those municipalities with FARC presence. Predetermined municipal controls includes logarithm of the population in 2010, municipality area, average elevation, distance to the closest major city, share of population under poverty, literacy rate, math and language test scores, index of rurality, log of tax income and index of good fiscal policy. Errors in parentheses control for spatial and first-order time correlation (see Conley, 1999, Conley, 2016). We allow spatial correlation to extend to up to $279 \mathrm{~km}$ from each municipality's centroid to ensure that each municipality has at least one neighbor. * is significant at the $10 \%$ level, ** is significant at the $5 \%$ level, *** is significant at the $1 \%$ level. 